\title{
Perils of development funding? The tale of EU Funds and grand corruption in Central and Eastern Europe ${ }^{1}$
}

Mihály Fazekas ${ }^{2}$ and Lawrence Peter King

University of Cambridge

Accepted for publication in Regulation and Governance on 25/8/2017

\section{Abstract}

Given the unprecedented scale of intergovernmental development funding and the importance of institutional quality for human wellbeing, it is imperative to precisely understand the impact of development funds on corruption. In Europe, EU Funds provide a boost to public spending in recipient member states while introducing additional corruption controls. We investigate whether EU Funds increase high-level corruption in the Czech Republic and Hungary in 20092012. We analyse newly collected data from over 100,000 public procurement contracts to develop objective corruption risk indicators and link them to agency-level data of the public sector. Propensity score matching estimations suggest that EU funds increase corruption risks by up to $34 \%$. The negative effects are largely attributable to overly formalistic compliance and EU Funds overriding domestic accountability mechanisms in public organisations entirely dependent on external funds. The policy implications are profound: governments should reduce barriers to market entry by lowering red tape and they should prevent excessive concentration of funds.

Keywords: corruption, EU Funds, public procurement, red tape, Big Data, Central and Eastern Europe

\footnotetext{
${ }^{1}$ Acknowledgements: The authors would like to thank the generous support of the European Union (FP7, grant agreement number: 290529) for financing much of the data collection efforts underpinning this research. We would also like to express our gratitude to numerous colleagues and friends commenting on earlier versions of this manuscript, in particular Nicholas Charron, Ramin Dadasov, Carl Dahlström, Victoria Dykes, Alexander Kentikelenis, Victor Lapuente, Alina Mungiu-Pippidi, Bernhard Reinsberg, Bo Rotstein, Bence Tóth, and Balázs Váradi.

2 Corresponding author: mf436@cam.ac.uk, +44 75874 3186, Free School Lane, CB2 3RQ, Cambridge, UK
} 


\section{Introduction}

Given the unprecedented scale of intergovernmental development funding and the importance of institutional quality for human wellbeing, it is imperative to understand the impact of development funds on grand corruption in recipient countries. EU Structural and Cohesion Funds (EU Funds henceforth) constitute a considerable part of GDP in recipient member states, especially in Central and Eastern Europe (CEE), where they amount to $1.9 \%-4.4 \%$ of annual GDP (KPMG, 2012) and well above 50\% of public investment. These funds represent the prime instrument supporting development in the EU's least developed regions, hence they are essential to the cohesion of the whole EU. Given their importance, EU funds come with strings attached, most notably enhanced bureaucratic controls, requirements of transparency, and strengthened oversight mechanisms - all aimed at preventing misuse of public money.

Unfortunately, it is hard to miss the 'buzz' around how corruption affects the spending of EU Funds across many new and old member states, from the Italian mafia hijacking highway projects to the European Commission freezing Structural Funds payments in Romania, Bulgaria, and Hungary. Some of these cases point to the involvement of high-level politics and organised criminal groups, raising the possibility that the EU in fact extensively finances largescale corruption in a number of countries. Even if only a fraction of such development funds is impacted by corruption, the negative effects are likely to be considerable in terms of malinvestment and distorted economic incentives, jeopardizing the territorial cohesion of the whole EU. If corruption in EU Funds spending is connected to high-level politics and organised crime, the ramifications are more severe, leading to distorted political competition and democracy.

Given the perceived weaknesses of corruption control in EU Funds spending (though to date there is little hard evidence of this), the large sums involved, and the potential negative consequences of corrupt misspending, this paper sets out to explore the impact of EU Funds 
spending on institutionalised grand corruption in CEE and to identify the main impact mechanisms.

We focus on the Czech Republic and Hungary in 2009-2012. These EU member states score close to the average of the Corruption Perception Index for CEE EU member states (53.25 in 2013) with scores of 48 and 54 respectively (Transparency International, 2013). They are considered to be successful reformers with GDP per capita converging to the EU average (reaching between $65-75 \%$ in 2009-2014) and both countries have avoided excessive, unsustainable budget deficits (close to or below the 3\% benchmark). Despite sharing similar post-communist heritage and levels of development, they differ in their recent institutional trajectories. Hungary is increasingly backsliding on measures of democracy, openness, and integrity, making it more akin to the most corrupt EU member states such as Romania or Bulgaria. At the same time, the Czech Republic has remained relatively stable with slow improvements over time, making it more closely associated with good governance achievers in the region like Estonia. Given these two EU member states' economic success and institutional framework, they represent the typical scenario for EU Funds spending: if corruption is increased by EU Funds in these countries, then it is likely to be the case in other recipient countries too. Given that even the poorest EU regions purport to have relatively high quality institutions compared to most aid recipients in the developing world, our findings can also depict an extreme case scenario for development funding globally.

EU Funds are spent in many ways, and corruption controls are set up in different configurations that make it impossible to offer a blanket assessment of their impact on corruption. To counter this problem, we focus on public procurement spending by public or semi-public organisations (e.g. state-owned enterprises) which are financed from EU Funds. We then compare EU Funds to national funds. This approach offers the advantage of comparing government contracts that are similar in most respects except the source of financing and the accompanying control mechanisms. This approach delivers valid conclusions as to whether EU Funds increase or decrease the level of corruption in recipient 
countries compared to domestic funds; it also allows us to investigate the mechanisms through which this impact occurs. Moreover, there is exceptionally good data available on public procurement spending between 2009-2012 in both countries at the individual contract level. This data has a unified data structure and source for EU as well as nationally funded contracts in both countries (note that public procurement regulations are identical regardless of funding source).

There are three main contributions of this article: theoretical, empirical, and policy-related. First, we bring together two rich strands of the literature -- aid dependence scholarship and the Europeanization literature -- which have been largely unconnected so far. Bringing these two together allows us to comprehensively map the causal pathways between development funding and recipient country corruption. Our novel theoretical argument understands bureaucratic controls of corruption as actual facilitators of corruption by drawing on the most recent theoretical developments in corruption studies, which define corruption as restricted access to public resources. Second, we gather micro-level administrative data and develop novel objective corruption proxies in order to address a fundamental developmental question which hitherto has been analysed either qualitatively or using perception-based corruption indices on the country level. Our large-scale, micro-level quantitative database unearths a detailed picture of corruption on the level of individual contracts while also being broad enough to evaluate whole systems of governance. This data also allows for utilizing a propensity score matching methodology for estimating the causal effects that is superior to previously used regression methods. Third, we bring new evidence to a policy question fundamental to the territorial cohesion as well as institutional legitimacy of the EU at a time when both are increasingly questioned by elites as well as the wider population. Through claiming that EU Funds actually increase corruption risks in recipient CEE countries, the identified causal pathways allow for developing effective policy interventions, namely decreasing the bureaucratic burden associated with EU Funds disbursement and preventing recipient public bodies' excessive reliance on such external funds. 
The rest of the article is structured as follows: first, the main theoretical considerations and hypotheses are set out; second, data and indicators are presented and validated; third, empirical results are discussed; finally, conclusions are drawn and promising policy remedies are highlighted.

\section{Conceptual frame}

\section{Corruption control mechanisms in EU Funds}

Spending EU Funds in comparison to national funds entails a more extensive accountability framework. First, it means public bodies have to comply with additional bureaucratic requirements, such as meeting ex-ante conditionalities and ex-post controls (Szabó et al., 2016). Second, it also implies that projects have to comply with more extensive transparency requirements like sending spending data to dedicated national transparency portals or reporting to the European Commission (European Commission, 2016). Third, EU Funds spending is also supervised by additional domestic and European control bodies. For example, the European Commission audits and approves national monitoring and governance institutions dedicated to EU Funds; it also maintains its own oversight institutions such as the European Anti-Fraud Office (OLAF) or the European Court of Auditors (European Commission, 2016).

While EU Funds come with additional controls, they also represent investment money on top of national sources while following a distinct governance logic. First, they have to comply with spending priorities and project approval criteria set out in the general Structural and Cohesion Funds framework, which is aimed at supporting the convergence of least developed regions. These priorities and criteria can be alien to domestic allocation mechanisms, especially on the local level. Second, in virtually all CEE recipient countries, they represent an ample funding source that is hard, if not impossible, to deplete. This is a problem which has been attributed to absorptive capacity and excessive bureaucratic controls (KPMG, 2012). Such abundance 
of funding is typically not the case for any national funding stream in the region. Third, EU Funds represent external funding with relatively little linked national contributions (typically about 15\%) (Szabó et al., 2016), diminishing the sense of ownership and responsibility among voters as well as within the public administration.

\section{Corruption and aid}

Despite the unique features of EU Funds that would imply they have sharply different impacts from national funds, there has been remarkably little scientific work on the question to date (Beblavy \& Sičáková-Beblavá, 2014; Mendrinou, 1994). There are, however, two bodies of literature that speak to this issue: the broad social science literature on aid dependence and the Europeanization literature in political science. Building on these two strands of thought, we derive a set of competing hypotheses that we can test.

In both literatures, various corruption definitions are used explicitly or implicitly, some equating corruption with bribery while others focus on high-level corruption and favouritism. This paper looks at elite-driven, institutionalised forms of corruption, as they can fundamentally challenge democratic party competition, inclusive policy making, and fair market competition. In the particular empirical context we concentrate on -- i.e. public procurement -- institutionalised grand corruption denotes the allocation and performance of public procurement contracts by bending prior explicit rules and principles of good public procurement in order to benefit a closed network while denying access to all others (Mungiu-Pippidi, 2006; North, Wallis, \& Weingast, 2009; Rothstein \& Teorell, 2008).

There is extensive literature looking at the effect development aid and its associated accountability mechanisms have on the quality of institutions and corruption. However, applying this research to the context of CEE countries and EU Funds should be done with caution due to the significantly differing contexts and funding volumes (e.g., EU funding amounts to 3-4\% of recipient countries' GDP, whereas many developing countries receive aid worth more than $10 \%$ of GDP). Hence, EU Funds in CEE can be considered an extreme case 
of development funding which is targeted at comparatively well-governed countries with substantial but relatively small spending values (i.e. financial dependence is more limited). According to this literature, foreign aid is expected to combat (high-level) corruption by providing clear policy goals like strengthening the civil service, improving bureaucratic control mechanisms, and overcoming the lack of resources for state building, as well as providing the resources to achieve these goals (Knack, 2001).

However, development aid can also increase corruption and impede state building in a similar way as natural resources can (Djankov, Montalvo, \& Reynal-Querol, 2008). It is expected to weaken domestic accountability mechanisms and the development of civil society by breaking the link between domestic revenues (i.e. taxation) and government services. It can also damage administrative capacity by (1) reallocating talented bureaucrats from domestic institutions to aid organisations and (2) providing additional organisational goals that undermine institutional cohesion (Knack \& Rahman, 2007). In addition, development aid also increases the pool of public resources available for rent seeking which easily translates into additional corruption in contexts with weak administrative controls of corruption and systemic high-level corruption (Bräutigam, 2000). While these causal pathways may work to different degrees in the CEE context, the above arguments may still account for a large part of the mechanisms linking EU Funds to corruption in the region. In particular, disconnecting local spending from local taxes and redirecting bureaucratic effort are two impact mechanisms which may play a considerable role in weakening domestic accountability mechanisms; accordingly, they play a central role in the subsequent analysis.

In the more specific Europeanization literature, few would debate that that the EU contributed to institution building and improvement of governance in CEE countries throughout the accession process (Epstein \& Sedelmeier, 2009). It provided the highly popular goal of EU accession for CEE governments and guidance on which institutional improvements should be implemented to reach this objective (Meyer-Sahling, 2011). This process resulted in substantial reforms of public administrations, augmentation of democratic checks and 
balances, and improvements in financial management. However, many authors expressed concerns that CEE countries reversed a range of reforms after accession and left many EUsupported and/or requested new rules as 'empty shells' (Epstein \& Sedelmeier, 2009; MungiuPippidi, 2007). These concerns stem from the EU's diminishing leverage to keep new member states in line with principles of good government and the perceived limited embeddedness of many pre-accession reforms. Many of these reforms were either 'implemented' only on paper, or they simply created islands of excellence isolated from the rest of public administration (Goetz, 2001).

Like the literature on aid dependency, the Europeanization literature argues that EU funds decrease corruption. First and most importantly, the disbursement of EU Funds is more heavily regulated, as was discussed above, which should make corruption more costly. Heavy administrative and regulatory requirements can also contribute to higher administrative capacity in the recipient organisations as they often have to invest in their bureaucracies to be able to receive and manage EU Funds. Second, extensive monitoring and controls of EU Funds, in addition to the usual national audit framework, make detection and punishment of corruption more likely than in projects funded with domestic funds (European Commission, 2003; European Court of Auditors, 2012, 2013). Moreover, the Court of Justice of the European Union represents an additional venue for judicial review, meaning would-be participants in corruption cannot necessarily count on the capture of domestic courts as an effective way of avoiding punishment (David-Barrett \& Fazekas, 2016). Third, one of Brussels' most important remaining post-accession levers for disciplining new member states is EU Funds and the threat of withdrawing them (Epstein \& Sedelmeier, 2009), which should motivate recipient countries' elites to limit high-level corruption in these funds.

Similar to the development aid literature, the Europeanization literature also argues that external funding, such as EU Funds in CEE, can damage the quality of government and increase corruption. First, EU Funds, like external funding in developing countries, weaken the link between domestic civil society, taxation, and policy performance. Second, EU funding 
provides a large additional pool of public resources for rent extraction, increasing the potential benefits from corruption (Mungiu-Pippidi, 2013). Third, EU Funds are spent on investment projects where public discretion is high. From the wider literature, it is clear that discretionary spending is more likely to involve corruption, especially high-level corruption, than nondiscretionary spending such as pensions (Mauro, 1998; Tanzi \& Davoodi, 2001). While all these mechanisms might be at play simultaneously, the repeated claims that EU Funds may cut the link between local spending from local taxes and distort bureaucratic effort compared to local policy preferences are of particular importance.

Following these theoretical arguments and building on an (sometimes only implicit) understanding in the literature that corruption results from the equilibrium between two countervailing forces, namely resources (discretion and resources) and constraints (legal, institutional, and normative) (Lambsdorff, 2007; Nye, 1967; Rose-Ackerman, 1999), we can succinctly summarize the main mechanisms through which EU Funds increase or decrease corruption risks compared to the default national public procurement spending (Figure 1). This comparison between the additional effects of EU Funds on top of national funding and national funding alone is exactly what our empirical analysis sets out to do later on.

$$
<<\text { Figure } 1 \text { here }>>
$$

Thus far it is clear that the relationship between EU Funds and high-level corruption is theoretically ambiguous; only empirical evidence can decide which mechanisms are stronger in CEE. Hence, we formulate the following hypothesis:

$\mathrm{H}_{1}$ : EU Funds increase institutionalised grand corruption in CEE.

While it is of crucial importance to identify the main effect of EU Funds, the question of which particular impact mechanism plays which role remains open. To this end, two impact channels are investigated in detail, as they feature centrally in the theoretical discussion and we possess sufficient data on them. The first mechanism through which EU Funds are expected to increase high-level corruption concerns redirected bureaucratic effort. That is, EU Funds entail 
many additional bureaucratic requirements that regulate and document bureaucratic processes. These additional requirements may weaken output orientation, encourage formalistic, 'on-paper' compliance, and impede open competition. In addition, demanding bureaucratic procedures act as a barrier to entry, directly decreasing the number of bidding firms hence encouraging the emergence of tight-knit networks of bureaucrats and businessmen. These arguments yield the following hypothesis:

$\mathrm{H}_{2}$ : EU Funds increase institutionalised grand corruption in CEE by redirecting bureaucratic effort toward formalistic, procedural compliance.

The second and related impact mechanism through which EU Funds can increase high-level corruption is their capacity to fundamentally reconfigure organisational behaviour and motivational structure. This is expected to take place when EU Funds become the dominant or even the exclusive funding source for a public body. This can substantially distort the link between local taxes, policy preferences, and the public body's spending behaviour, leading to weakened domestic accountability mechanisms. In contrast, when EU Funds represent a small to marginal proportion of total organisational procurement spending (i.e. low EU Funds spending intensity), they will most likely have no discernible impact on overall organisational behaviour. In addition, financial penalties for mismanaging funds are typically borne by the central budget rather than the implementing agency, further disconnecting local policy performance and local budgets and taxes. This non-linear effect of EU Funds concentrated at the upper end of the EU Funds spending intensity distribution leads to the following hypothesis:

$\mathrm{H}_{3}$ : EU Funds increase institutionalised grand corruption in CEE for public bodies that are predominantly financed by EU Funds. 


\section{Data and variables}

Data

The database derives from official public procurement announcements between 2009-2012 in the Czech Republic and Hungary. The data represent a complete database of all public procurement procedures conducted under national public procurement laws regardless of the funding source (e.g. national funds or EU Funds). All government contracts above a given value threshold have to follow the transparency and procedural rules set out in legislation with a few exceptions, such as contracts of national security concern (for exact thresholds, see Appendix A). The database contains variables appearing in 1) calls for tenders, such as product specification, application deadline, or assessment criteria; 2) contract award notices, such as name of the winner, awarded contract value, or date of contract signature; 3) contract modification notices, such as the modified contract value; and 4) administrative corrections notices, containing the corrected value of any variable appearing in the other announcement types. As not all of these kinds of announcements appear for each procedure, for example depending on procedure type, we only have the information deriving from contract award notices consistently across every procedure. Both countries' respective public procurement legislation is within the framework of the EU Public Procurement Directive and they are thus largely comparable.

The data derive from official government online sources in each country (Appendix A) and the full database can be downloaded at digwhist.eu/resources/data. As there is no readily available database, we used a crawler algorithm to capture every announcement available online. Then, applying a complex automatic and manual text mining strategy, we created a structured database that contains variables with well-defined categories. As the original texts 
available online contain a range of errors, inconsistencies, and omissions, we applied several correction measures to arrive at a database of sufficient quality for scientific research. ${ }^{3}$

The resulting database describes at the micro-level a considerable proportion of GDP and public spending in these countries (Table 1).

$$
<<\text { Table } 1 \text { here }>>
$$

\section{Variables used in the analysis}

As the main independent variable, the analysis looks at EU Funds use, both on the contract and organisational levels. For key dependent variables, the analysis takes corruption risk indicators, both as a single score and decomposed into individual components. Below we briefly define each of them.

\section{EU Funds use}

The spending of EU Funds in public procurement can be directly identified in each contract award announcement as it is mandatory to report whether EU Funds are used. No information is published on the proportion of EU funding within the total contract value. Hence, we had to employ a yes-no categorisation of each contract awarded. In most cases, regulation allows for the EU contribution to cover $80-95 \%$ of total investment; this threshold is typically reached due to the abundance of EU Funds. This paper's accounting approach must necessarily disregard the national co-financing of $5-20 \%$ of contract value. When calculating the share of EU Funds in total organisational procurement, we sum the contract value of all EU funded contracts and calculate their share in the total contract value awarded in a year.

\footnotetext{
${ }^{3}$ For example, only the Czech Republic has a unique procedure ID for contract award announcements and calls for tenders. In Hungary, the announcements refer to each other in varying formats, making our linking procedure imperfect. For further description of database development, see Soudek \& Skuhrovec (2013) on the Czech Republic and Fazekas \& Tóth (2012a, 2012b) on Hungary.
} 
Public procurement from EU Funds falls under the same procurement rules and thresholds as other funding sources. Common national and European public procurement legal frameworks warrant a meaningful comparison between EU funded and non-EU funded public procurement tenders. The crucial difference between these two types of tenders lies in additional monitoring and controls EU involvement brings, as well as the different motivation structures associated with spending EU Funds. The Czech Republic and Hungary have made use of EU funding in their procurement spending to broadly similar degrees, with Hungary drawing on EU Funds somewhat more extensively (Table 2 ).

$<<$ Table 2 here $>>$

\section{Indicators of institutionalised grand corruption}

Developing comparative indicators of institutionalised grand corruption in public procurement for both countries represents the primary methodological innovation of this article, addressing a gap long recognised in the literature (Knack, 2006). Our approach builds on prior scholarship with similar datasets, making use of a range of public procurement 'red flags' across Europe (Charron, Dahlström, Fazekas, \& Lapuente, 2017; Fazekas \& Kocsis, 2017; Klasnja, 2016; Mungiu-Pippidi, 2016).

The measurement approach exploits the fact that for institutionalised grand corruption to work, procurement contracts have to be awarded recurrently to companies belonging to the corrupt network. This can only be achieved if legally prescribed principles of fair competition and open access are circumvented by public officials during the implementation of procurement rules. By implication, it is possible to identify the input side of the corruption process, that is techniques used for limiting competition (e.g. leaving too little time for bidders to submit their bids) as well as the output side of corruption, that is signs of limited competition (e.g. single bid received and recurrent contract award to the same company). By measuring the degree of unfair restriction of competition in public procurement, proxy indicators of corruption can be obtained. 
Based on qualitative interviews about corruption in the public procurement process in Hungary and the Czech Republic, a media content analysis in Hungary, and a review of international literature (Fazekas, Cingolani, \& Tóth, 2016; Klasnja, 2016; OECD, 2007; Pricewaterhouse Coopers, 2013; World Bank, 2009), we identified a range of 'red flags' indicating corruption risks in public procurement (Table 3). The simplest indication of restricted competition in line with our theoretical definition is when only one bid is submitted for a tender in an otherwise competitive market. Single bidding typically allows the awarding of contracts above market prices and extracting corrupt rents (output side). Hence, the incidence of single bidder contracts awarded (i.e. contracts awarded in procurement tenders where only one bid was received by the contracting authority) is the most basic corruption proxy we propose.

A more complex indication of high-level corruption incorporates characteristics of the tendering process that are in the hands of public officials who conduct the tender and contribute to competition restriction (input side). This more encompassing composite indicator is called the Corruption Risk Index (CRI). It consists of the following components (note that single bidding is also included):

1. One of the most straightforward 'red flag' of corruption is a single bid being submitted. Since we are only examining competitive markets, the apparent lack of competition allows for awarding above-market price contracts and extracting corrupt rents.

2. On competitive markets, it is unlikely to have the same company winning all the contracts of a given issuer, hence the very high share of the winning company within all the contracts awarded by the issuer in a given period can indicate rigged competition. Both a single bid being submitted and the winner's high contract share are two outcomes of the competitive process which closely match the concept of institutionalised grand corruption in addition to having been identified as most reliable 'red flags' in the literature (Kenny \& Musatova, 2010).

3. A simple way to fix tenders is to decline to publish a call for tenders in the official public procurement journal, as this would make it harder for competitors to prepare a bid. 
4. Call for tender announcements provide the key document upon which bidding firms base their bids. Changing the bidding conditions such as technical content or eligibility criteria once or more after official publication creates uncertainty and can deter bidders, serving corrupt purposes.

5. While open competition is relatively hard to avoid in some tendering procedure types, such as open tender, others, such as invitation tenders, are by default much less competitive; hence using less open and less transparent procedure types can indicate the deliberate limitation of competition, hence corruption risks.

6. Eligibility criteria define which companies are allowed to bid. Tailoring the conditions to a single company is one of the most widely quoted means for corruptly limiting competition. Overly complex, hence lengthy criteria, are typical signs that criteria were 'over-specified', most likely to the detriment of would-be competitors.

7. If the advertisement period -- i.e. the number of days between advertising a tender and the submission deadline -- is too short for preparing an adequate bid, it can serve corrupt purposes whereby the issuer informally tells the well-connected company about the opportunity much earlier.

8. Different types of evaluation criteria are prone to different degrees of manipulation. Subjective, hard-to-quantify criteria often accompany rigged assessment procedures, as they create room for discretion and limit accountability mechanisms.

9. If the time used for deciding on the submitted bids is excessively short or lengthened by legal challenge, this can also signal corruption risks. Snap decisions may reflect premediated assessment, while legal challenge and the corresponding long decision period suggest outright violation of laws.

$$
<<\text { Table } 3 \text { here }>>
$$

Regressions were used to identify reliable and valid corruption proxies ("red flags"). Regressions aimed to directly model corrupt behaviour in public procurement by taking the two tendering outcomes that best capture our corruption definition as dependent variables: 
single bidding and winner contract share. As independent variables, we used proxies of corrupt tendering processes (lack of publishing the call for tender, strategically modifying tender conditions, using non-open procedure types, etc.). These two regression set-ups closely approximate how a corruptly colluding public body and bidding firm would behave (e.g. applying short advertisement periods so that more productive competitors cannot reasonably bid), while also identifying bad procurement practice not associated with corruption (e.g. single bid submitted in the absence of a short advertisement period). To ensure our "red flags" measure corruption rather than incompetence or lack of competing firms, we restricted the sample to experienced contracting bodies tendering in competitive markets; that is, we only examine tenders in markets with at least 3 unique winners throughout 2009-2012, where markets are defined by product type (CPV ${ }^{4}$ level 3 ) and location (NUTS 5 level 1); and issuers that have awarded at least 3 contracts in the 12 months period prior to the contract award in question. In addition, we also included a number of likely confounders in the regressions: (1) administrative capacity measured by number of employees of the issuer ${ }^{6}$; (2) institutional endowments measured by type of issuer (e.g. municipal, national); (3) product market and technological specificities measured by CPV division of products procured; (4) number of competitors on the market measured by the number of unique winners throughout 2009-2012 on CPV level-3 product group and NUTS-1 geographic region; (5) contract size and length; and (6) regulatory changes as proxied by year of contract award. For full regression results, see Appendix B; for descriptive statistics of the resulting proxy indicators, see Table 4.

For continuous corruption proxies such as the length of submission period (measured in days), thresholds had to be identified in order to reflect the non-linear character of corruption. This is because most values of continuous variables can be considered as reflections of diverse market practices, while some domains of outlier values are more associated with corruption.

\footnotetext{
${ }^{4} \mathrm{CPV}=$ Common Procurement Vocabulary. For more info see: http://simap.europa.eu/codes-andnomenclatures/codes-cpv/codes-cpv en.htm

5 NUTS=Nomenclature of territorial units for statistics. For more info see: http://epp.eurostat.ec.europa.eu/portal/page/portal/nuts nomenclature/introduction

${ }^{6}$ Employment data derives from national administrative databases.
} 
For example, giving 30-40 days for companies to prepare their bids carries little to no information on corruption risks, whereas when the advertisement period diminishes to 5-10 days most experts suggest a spike in the risk of corruption. For more details on the identification of thresholds see (Fazekas, Tóth, \& King, 2016).

Once the regressions established the elementary validity of each corruption proxy ${ }^{7}$ (for further validity tests see the next section), we could calculate an arguably very simple indicator single bidding - and a more complex composite indicator - the Corruption Risk Index (CRI). Reflecting the lack of detailed knowledge of which elementary corruption technique is a necessary, sufficient, or more important condition for corruption to occur, CRI is a simple arithmetic average of all 9 corruption proxies each falling in the $0-1$ range.

Each of the two corruption risk indicators, single bidding and $\mathrm{CRI}$, has pros and cons. The strength of the single bidder indicator is that it is very simple and straightforward to interpret. However, its simplicity makes it more prone to gaming by corrupt actors, such as through the inclusion of fake bidders to mimic competition. The strength of the composite indicator approach $(\mathrm{CRI})$ is that it explicitly tries to abstract from diverse market realities to capture the underlying corruption techniques. It allows for 'red flag' definitions to change from context to context in order to best capture the deviation from prevailing open and fair competitive norms. In addition, as corruption techniques used at any point in time are likely to be diverse in nature, tracking multiple possible corruption strategies in one composite score is the best method of ensuring consistent results even if the composition of underlying corruption techniques changes. Both of these characteristics underpin CRI's usefulness for international and timeseries comparative research. The main weakness of $\mathrm{CRI}$ is that it can only capture a subset of corruption strategies in public procurement, arguably the simplest ones; it misses out on sophisticated types of corruption, such as corruption combined with inter-bidder collusion. But

\footnotetext{
7 The winner contract share indicator has received less extensive discussion in this article, please refer to prior work for more details on it (Fazekas, Tóth, et al., 2016).
} 
as long as the simplest strategies are the cheapest for corrupt groups, they are likely to represent the most widespread forms of corrupt behaviour.

$<<$ Table 4 here >>

\section{Validity of corruption proxies}

First, institutionalised grand corruption thrives on rents extracted from public procurement contracts, often through higher-than-competitive prices ${ }^{8}$. As detailed information on unit prices is missing, the only way to determine how expensive public procurement was is to compare the originally estimated contract value with the final contract value. Higher values of the ratio of contract value to estimated contract value indicate more expensive tenders (Ishii, 2009; Padhi \& Mohapatra, 2011). By implication, this price ratio is expected to be positively associated with corruption risks.

We find the expected relationship: both single bidder contracts and a higher $\mathrm{CRI}$ are associated with higher prices in linear regressions explaining relative contract price with single bidding or $\mathrm{CRI}$ while including control variables such as type of issuer, number of employees, product market, year of contract award, and log contract value (Table 5). While effect sizes differ somewhat by country, they indicate that contracts awarded in the presence of 'red flags' are considerably more expensive: single bidder contracts have between 6-15\% higher prices than multiple bidder contracts; similarly, contracts with one additional red flag (i.e. 1/9 CRI points higher) are $2-3 \%$ more pricey even after controlling for major confounding factors.

$$
<<\text { Table } 5 \text { here }>>
$$

Second, personal connections underpinning corrupt contracting are more likely to arise among local actors of close geographical proximity, such as organisations situated in the same town

\footnotetext{
${ }^{8}$ A more comprehensive assessment of indicator validity is provided for the Hungarian CRI by the authors (Fazekas, Tóth, et al., 2016), In this paper we show that CRI in Hungary is correlated with higher profitability, politicians as owners or managers of companies, and company registration in offshore tax havens.
} 
or region (Coviello \& Gagliarducci, 2010; Lewis-Faupel, Neggers, Olken, \& Pande, 2014). Hence, local firms are expected to contract in the presence of higher corruption risks than their non-local peers, all else being equal. This is exactly the relationship we find in the Czech Republic and Hungary: $7 \%^{*}$ and $0 \%$ higher single bidder share; $0.05^{*}$ and $0.01^{*}$ points higher $\mathrm{CRI}$ respectively (differences marked with $\mathrm{a}{ }^{*}$ are significant at the conventional $5 \%$ level). Further validity tests using Hungarian and pan-EU data provide evidence of indicator validity (Fazekas \& Kocsis, 2017; Fazekas, Tóth, et al., 2016). For example, in Hungary, non-domestic public procurement suppliers that are registered in tax havens such as Cyprus or Luxembourg have about $20 \%$ higher $\mathrm{CRI}$ score than companies registered in transparent jurisdictions such as Germany (significant at the conventional 5\% level).

\section{Results}

Each of the three hypotheses is evaluated in turn below: first, the overall effect of additional external funding (EU Funds) on corruption risks is gauged. As EU Funds represent a bundle of effects on corruption, two detailed tests of impact mechanisms are explored. Second, individual risk components are compared across EU and nationally funded procurement contracts to determine the degree to which compliance is formalistic and administrative as opposed to substantive, leading to open and fair competition for government contracts. Third, public organisations making use of EU funding to different degrees are assessed in order to better understand whether those bodies whose spending is composed of $100 \%$ or close to $100 \%$ EU Funds behave differently than those where EU Funds represent a small portion of organisational spending. We expect organisations solely spending EU Funds to be most detached from domestic accountability mechanisms, hence the highest corruption risk. 
In the absence of random assignment to EU and national funding, the causal effect of EU Funds on corruption risks is estimated by matching contracts funded from national sources (control group) to tenders funded by the EU (treatment group) and comparing the two groups in terms of corruption risks. This approach directly reflects the theoretical framework by comparing the default funding source (national) to the funds representing additional resources as well as controls (EU Funds) on top of the national framework. Comparing tenders which are as similar as possible in every relevant respect except funding source allows for the approximation of the causal impact. The obvious limitation of this approach is that we cannot measure all the confounding factors, hence we cannot fully account for all the systematic differences between EU and nationally funded contracts contributing to corruption risks (i.e. the unconfoundedness condition may not be fully met). Thus, we employ state of the art matching methods which are widely employed in the program evaluation literature (Imbens \& Wooldridge, 2009).

Matching is superior to the simple, unmatched comparison of group means as long as the selection of EU-funded projects is itself not driven by corrupt considerations such as deliberately channelling EU Funds to markets where hiding corruption is easier. If selection is predominantly driven by corruption, the simple comparison is more appropriate than matching. As it is unclear to what degree EU Funds selection is driven by corrupt considerations, we interpret matched results as a lower bound and simple comparisons as an upper bound estimate of the causal impact.

A baseline comparison of average corruption risk indicators without matching suggests that EU funded public procurement carries higher corruption risks than nationally funded public procurement (Table 6). EU funded procurement has a $9.6 \%$ higher single bidder share and 0.04 point higher $\mathrm{CRI}$ than nationally funded procurement. Both of these differences are statistically significant and substantial compared to the baseline risk scores $(28.1 \%$ single bidder share or 0.29 points $\mathrm{CRI}$ ). However, these comparisons may very well be biased, as EU and non-EU funded projects could be fundamentally different. For example, EU funded 
tenders are on average $12 \%$ larger than nationally funded tenders, hence they tend to be somewhat more complex.

Therefore, we employ a propensity score matching technique that matches contracts that are as similar as possible in terms of 1) the main market of procured goods and services (2-digit DPV categories); 2) number of competitors on the market; 3) log contract value ${ }^{9}$; 4) year of contract award; 5) location of contract performance (NUTS1 regions); 6) type of procuring body (categories are listed in Table 4, lower panel); and 7) share of EU Funds within total organisational spending between 2009-2012. These confounding factors are controlled for as corruption risks and can be very different along these dimensions. While further controls could make our estimates more reliable, there are no further covariates which we could draw on in the database, and we believe that the major confounding factors are proxied with our approach. ${ }^{10}$

Propensity score matching, taking into account confounding factors, reveals a similar picture as above, albeit one with slightly smaller effect magnitudes (Table 6$)^{11}$. In the matched samples, EU funded procurement has $6.3 \%$ points higher single bidder share and 0.02 point higher CRI than nationally funded procurement. Both of these differences are statistically significant and substantial compared to the baseline risk scores $(30.4 \%$ single bidder share or 0.30 points $\mathrm{CRI})$.

$<<$ Table 6 here >>

These results provide supporting evidence in favour of $\mathrm{H}_{1}$ : EU Funds increase institutionalised grand corruption in CEE. In order to better understand effect magnitudes, the price impact of the changes in single bidder percentages is calculated: given that single bidder contracts are

\footnotetext{
${ }^{9}$ In addition, our matching was also repeated using subsamples excluding below national reporting threshold contracts, i.e. contracts with value below 40,000 EUR; and excluding below EU-level reporting threshold contracts, i.e. 140,000 EUR. For full robustness test results see Appendix D.

10 Potentially relevant missing variables which we would have been happy to use are variables characterising the projects the contracts belong to.

11 See Appendix C for goodness of propensity score matching.
} 
6-15\% more expensive than multiple bidder contracts, EU Funds' increased corruption risks pushed procurement prices up by an estimated 218-229 million EUR in 2009-2012, or $0.02 \%$ of GDP in the Czech Republic and Hungary combined.

\section{Bureaucratic controls and formalistic compliance}

While the identified causal effect of EU Funds on corruption risks provides supporting evidence for $\mathrm{H}_{1}$, it fails to provide sufficient detail on the nature of impact mechanisms. In order to address this shortcoming, we now turn to $\mathrm{H}_{2}$ by exploring the differences between EU and nationally funded public procurement tenders on the level of individual risk factors by differentiating three types of corruption risks: i) easily observable and tightly monitored procedural risks (procedure type and not published call for tender); ii) hard to observe or benchmark, hence only partially monitored, procedural risks (length of eligibility criteria, weight of non-quantitative criteria, length of decision period, and modification of call for tenders); and iii) risks associated with bidding outcomes not monitored explicitly (single bidder and winner contract share). If, as $\mathrm{H}_{2}$ proposes, EU Funds redirect bureaucratic effort to formalistic, procedural compliance and away from substantive compliance supporting value for money and open competition, we expect to see three empirical patterns: i) easily observable and tightly monitored risks are lower in EU Funds than in national funds; ii) risk factors less readily observable and thus only partially monitored by EU control institutions are higher in EU than national funds; and iii) corruption risks directly capturing competitive outcomes are also higher in EU than national funds, reflecting barriers to entry and the emergence of corrupt collusive networks between public bodies and selected bidding firms.

In line with $\mathrm{H}_{2}$, EU Funds have lower or equal corruption ${ }^{12}$ risks than national funds in the most visible procedural risks tightly monitored by oversight bodies (Table 7). First, procedure type risks are lower in EU funded procurement than in nationally funded, while not publishing the

\footnotetext{
12 The fact that tight monitoring lowers selected observed corruption risks underlines the need for a broad-based corruption risk measurement methodology and a flexible measurement approach tracking changing organisational behaviour.
} 
call for tenders in the official journal and leaving sufficient amount of time for publicizing a call are indistinguishable in the two groups. Second, more subtle and thus less readily monitored risks are more prevalent in EU Funds than in national funds: length of eligibility criteria, weight of non-quantitative assessment criteria, decision period length, and modifications to call for tenders are all more frequently present in EU funded procurement. Third and probably most importantly, risks present in tendering outcomes indicating whether competition is open and fair -- such as single bidding and winner contract share -- are both considerably higher in EU Funds than in national funds: single bidding is $8.7-8.9 \%$ more prevalent, while the winner's contract share is $4.8-6.0 \%$ higher in EU Funds.

$<<$ Table 7 here $>>$

\section{EU Funds spending concentration}

The emerging evidence so far has been that bureaucratic controls associated with EU Funds increase corruption risks by encouraging formalistic compliance rather than genuinely open and fair competition. However, this picture is still incomplete, as we know relatively little about how EU Funds change organisational behaviour and accountability mechanisms that public organisations are subject to. As $\mathrm{H}_{3}$ suggests, those public bodies which predominantly or even exclusively spend from EU Funds are more detached from domestic accountability mechanisms (e.g. linking domestic taxation to local spending) and are driven by EU funding priorities and controls to a greater degree. This is expected to exacerbate the negative effects we have found thus far.

In order to test $\mathrm{H}_{3}$ on the level of public organisations, we aggregated the contract-level database to the organisation level and ran a panel regression analysis on an annual basis between 2009 and 2012 (Table 8). In these regressions, the dependent variable is the CRI and the independent variable of interest is the share of EU funded contracts in total procurement spending (for the same regressions with single bidder $\%$ as dependent variable see Appendix E, findings are qualitatively the same). In line with preceding evidence, 
organisations relying more extensively on EU Funds in their overall procurement spending are those that have higher total corruption risks. This effect is robust to multiple regression specifications: pooled OLS, between effects and random effects estimators (Models 1-3) while controlling for main organisational characteristics such as country, organization type (e.g. local or public utility), main sector (e.g. general public services or education), log spending value, number of employees, and use of state-of-the-art procurement tools (i.e. use of e-auctions). A Hausman test suggests the more efficient random effects estimator can be used $(p=0.36)$. The effect remains essentially unchanged when using the lagged value of EU Funds' share lending some support to a causal interpretation (Models 4-5). Most importantly, when considering the categorical rather than linear effect of EU Funds' share, we find that most of the effect comes from the upper end of the distribution that is organisations funding their procurement spending almost entirely or entirely from EU Funds. Compared to organisations only making use of national funds, organisations with $75-99 \%$ EU funding achieve a CRI 0.01 points higher while those with $100 \%$ EU funding achieve 0.02 points higher (the same values for single bidding are $3 \%$ and 3.3\%). Organisations with little to moderate amount of EU Funds, $1-74 \%$ EU Funds share, are statistically indistinguishable from public bodies with $0 \%$ EU funded procurement spending. This pronounced non-linearity suggests that it is the near complete replacement of domestic accountability mechanisms and domestic funding sources by EU Funds which produce the observed deteriorating corruption levels (i.e. increasing corruption risks), supporting $\mathrm{H}_{3}$.

$<<$ Table 8 here $>>$

Appendix F contains results from the same regression specification, but on a sample restricted to municipalities representing a more homogenous sample where democratic controls are most direct (i.e. direct election of mayors and municipal councils) and no specialised agencies are included, such as a National Infrastructure Agency where EU Funds concentration could be correlated with the organisation type and goals. In this subsample results are essentially the same, while effect magnitudes increase. Compared to organisations only making use of 
national funds, organisations with 75-99\% EU funding achieve a CRI 0.02 points higher while those with $100 \%$ EU funding achieve 0.03 points higher.

\section{Conclusions}

Findings suggest that accountability mechanisms and resources associated with EU Structural and Cohesion Funds increase institutionalised grand corruption in two characteristic countries of CEE: the Czech Republic and Hungary. The estimated effect is highly significant and nonnegligible: EU Funds increase corruption risks by up to $34 \%$ compared to national democratic accountability mechanisms (single bidding ratio increasing from 0.28 to 0.38 , see Table 6 ). Using a back-of-the-envelope calculation, this increases contracting costs between 2009-2012 by an estimated $218-229$ million EUR, or $0.02 \%$ of the two countries' combined GDP.

We attribute a considerable portion of the negative impact of EU Funds to two impact mechanisms: i) formalistic, administrative compliance with prescriptions rather than a genuine improvement in competitive outcomes like the number of bidders; and ii) the negative effects are predominantly driven by public organisations where EU Funds represent the overwhelming majority of organisational procurement spending. It is these organizations that are most insulated from national accountability mechanisms and funding channels.

The policy consequences of our analysis are profound. Our findings suggest that in order to better control corruption in Structural and Regional Funds, the EU should focus on increasing access to and competition for its funds disbursed in the least developed regions instead of excessively relying on bureaucratic controls to better control corruption (Duvanova, 2014). In addition, it also follows that excessive EU Funds reliance of recipient public bodies should be avoided in order to maintain the link between local taxes, local policy performance, and local civil society oversight. For example, policy makers could set upper limits on the ratio of EU Funds to own funds for beneficiary organisations. And as this analysis has already 
demonstrated, using Big Data solutions to monitor competitive outcomes and identify red flags early on can support accountability in EU Funds spending.

Further research could replicate this article's methodology in other EU member states (and even for donor spending in developing countries), which would contribute to a comprehensive corruption monitoring framework. More work would be needed to unearth if similar effects and mechanisms are present in other countries and to provide a more detailed picture of how bureaucracies respond to incentives presented by EU Funds (e.g. looking at how bureaucratic resources are shared between EU and national funds). Further research could also map out a wider range of impact mechanisms accounting for a larger portion of the total variance of the observed impact. For example, by linking company information to public procurement records, companies' reliance on government contracts and EU Funds could be explored as a further determinant of corruption risks. Linking publicly available, detailed information on EU funded projects to the corresponding procurement tenders would allow researchers to explore the interactions between EU Funds and national spending in even greater detail. 


\section{References}

Beblavy, M., \& Sičáková-Beblavá, E. (2014). The Changing Faces of Europeanisation: How Did the European Union Influence Corruption in Slovakia Before and After Accession? Europe-Asia Studies, 66(4), 536-556.

Bräutigam, D. A. (2000). Aid Dependence and Governance. Stockholm: Almqvist \& Wiksell International.

Charron, N., Dahlström, C., Fazekas, M., \& Lapuente, V. (2017). Careers, Connections, and Corruption Risks: Investigating the impact of bureaucratic meritocracy on public procurement processes. Journal of Politics, 79(1), 89-103.

Coviello, D., \& Gagliarducci, S. (2010). Building Political Collusion: Evidence from Procurement Auctions (IZA Discussion Papers No. 4939). IZA DP No. 4939, Bonn: Institute for the Study of Labor (IZA).

David-Barrett, E., \& Fazekas, M. (2016). Corrupt Contracting: Partisan Favouritism in Public Procurement. Hungary and the United Kingdom Compared.

Djankov, S., Montalvo, J., \& Reynal-Querol, M. (2008). The curse of aid. Journal of Economic Growth, 13(3), 169-194.

Duvanova, D. (2014). Economic Regulations, Red Tape, and Bureaucratic Corruption in PostCommunist Economies. World Development, 59, 298-312.

Epstein, R. A., \& Sedelmeier, U. (Eds.). (2009). International influence beyond conditionality: postcommunist Europe after EU enlargement. London: Routledge.

European Commission. (2003). A Comprehensive EU Policy Against Corruption. Brussels.

European Commission. (2016). Beginner's guide to EU funding. Brussels.

European Court of Auditors. (2012). Annual Report on the Implementation of the Budget concerning financial year 2011. Brussels.

European Court of Auditors. (2013). Are EU Cohesion Policy funds well spent on roads? Luxembourg: European Court of Auditors.

Fazekas, M., Cingolani, L., \& Tóth, B. (2016). A comprehensive review of objective corruption proxies in public procurement: risky actors, transactions, and vehicles of rent extraction (Government Transparency Institute Working Paper Series No. GTI-WP/2016:03). Budapest.

Fazekas, M., \& Kocsis, G. (2017). Uncovering High-Level Corruption: Cross-National Corruption Proxies Using Government Contracting Data. British Journal of Political Science.

Fazekas, M., \& Tóth, I. J. (2012a). Hibák, javitások és elözetes eredmények - magyarországi közbeszerzések 2010-2011. Corruption Research Centre, Budapest.

Fazekas, M., \& Tóth, I. J. (2012b). Public Procurement, Corruption and State Capacity in Hungary - objective measures and new insights. Corruption Research Centre, Budapest.

Fazekas, M., Tóth, I. J., \& King, L. P. (2016). An Objective Corruption Risk Index Using Public Procurement Data. European Journal of Criminal Policy and Research, 22(3), 369-397.

Goetz, K. H. (2001). Making sense of post-communist central administration: modernization, Europeanization or Latinization? Journal of European Public Policy, 8(6), 1032-1051.

Ishii, R. (2009). Favor exchange in collusion: Empirical study of repeated procurement auctions in Japan. International Journal of Industrial Organization, 27(2), 137-144.

Kenny, C., \& Musatova, M. (2010). "Red Flags of Corruption" in World Bank Projects: An 
Analysis of Infrastructure Contracts (Policy Research Working Paper No. 5243) (p. Policy Research Working Paper 5243, World Bank, Washington DC). Washington, DC.

Klasnja, M. (2016). Corruption and the Incumbency Disadvantage: Theory and Evidence. Journal of Politics, 77(4), 928-942.

Knack, S. (2001). Aid Dependence and the Quality of Governance: Cross-Country Empirical Tests. Southern Economic Journal, 68(2), 310-329.

Knack, S. (2006). Measuring corruption in Eastern Europe and Central Asia: A critique of the cross-country indicators (World Bank Policy Research Working Paper No. 3968). Washington, DC.

Knack, S., \& Rahman, A. (2007). Donor fragmentation and bureaucratic quality in aid recipients. Journal of Development Economics, 83(1), 176-197.

KPMG. (2012). EU Funds in Central and Eastern Europe. 2011. Warsaw, Poland: KPMG.

Lambsdorff, J. (2007). The Methodology of the Corruption Perceptions Index 2007. Transparency International (TI) and University of Passau.

Lewis-Faupel, S., Neggers, Y., Olken, B. A., \& Pande, R. (2014). Can Electronic Procurement Improve Infrastructure Provision? Evidence From Public Works in India and Indonesia (NBER Working Paper Series No. 20344).

Mauro, P. (1998). Corruption and the composition of government expenditure. Journal of Public Economics, 69, 263-279.

Mendrinou, M. (1994). European Community fraud and the politics of institutional development. European Journal of Political Research, 26(1), 81-101.

Meyer-Sahling, J.-H. (2011). The Durability of EU Civil Service Policy in Central and Eastern Europe after Accession. Governance: An International Journal of Policy, Administration and Institutions, 24(2), 231-260.

Mungiu-Pippidi, A. (2006). Corruption: Diagnosis and Treatment. Journal of Democracy, 17(3), 86-99.

Mungiu-Pippidi, A. (2007). EU Accession is no "End of History." Journal of Democracy, 18(4), 8-16.

Mungiu-Pippidi, A. (Ed.). (2013). Controlling Corruption in Europe. The Anticorruption Report 1. Berlin: Barbara Budrich Publishers.

Mungiu-Pippidi, A. (2016). For a New Generation of Objective Indicators in Governance and Corruption Studies. European Journal of Criminal Policy and Research, 22(3), 1-5.

North, D. C., Wallis, J. J., \& Weingast, B. R. (2009). Violence and Social Orders. A Conceptual Framework for Interpreting Recorded Human History. Cambridge, UK: Cambridge University Press.

Nye, J. S. (1967). Corruption and Political Development: A Cost-Benefit Analysis. The American Political Science Review, 61(2), 417-427.

OECD. (2007). Integrity in Public Procurement. Good Practice from A to Z. Paris: OECD.

OECD. (2013). Government at a Glance 2013. Paris: OECD.

Padhi, S. S., \& Mohapatra, P. K. (2011). Detection of collusion in government procurement auctions. Journal of Purchasing and Supply Management, 17(4), 207-221.

Pricewaterhouse Coopers. (2013). Identifying and reducing corruption in public procurement in the EU. Brussels: PricewaterhouseCoopers and Ecorys.

Rose-Ackerman, S. (1999). Corruption and Government: Causes, Consequences, and Reform. Cambridge, UK: Cambridge University Press.

Rothstein, B., \& Teorell, J. (2008). What Is Quality of Government? A Theory of Impartial 
Government Institutions. Governance, 21(2), 165-190.

Soudek, J., \& Skuhrovec, J. (2013). Public Procurement of Homogeneous Goods: the Czech Republic Case Study (IES Working Paper No. 05/2013). IES Working Paper 05/2013. IES FSV. Prague: Charles University.

Szabó, Z., Balás, G., Borbás, G., Kiss, G., Piross, A., Potvorszki, G., \& Szerletics, Á. (2016). Európai Uniós Források Rendszere 2014-2020. Gyakorlati útmutató pályázókak és pályáztatóknak. Budapest: Pátria Nyomda.

Tanzi, V., \& Davoodi, H. (2001). Corruption, growth, and public finances. In A. K. Jain (Ed.), The Political Economy of Corruption (pp. 89-110). New York: Routledge.

Transparency International. (2013). Global Corruption Barometer 2013. Berlin: Transparency International.

World Bank. (2009). Fraud and Corruption. Awareness Handbook. Washington DC: World Bank. 
Figures

Figure 1. Overview of causal mechanisms through which national and EU finding influences high-level corruption

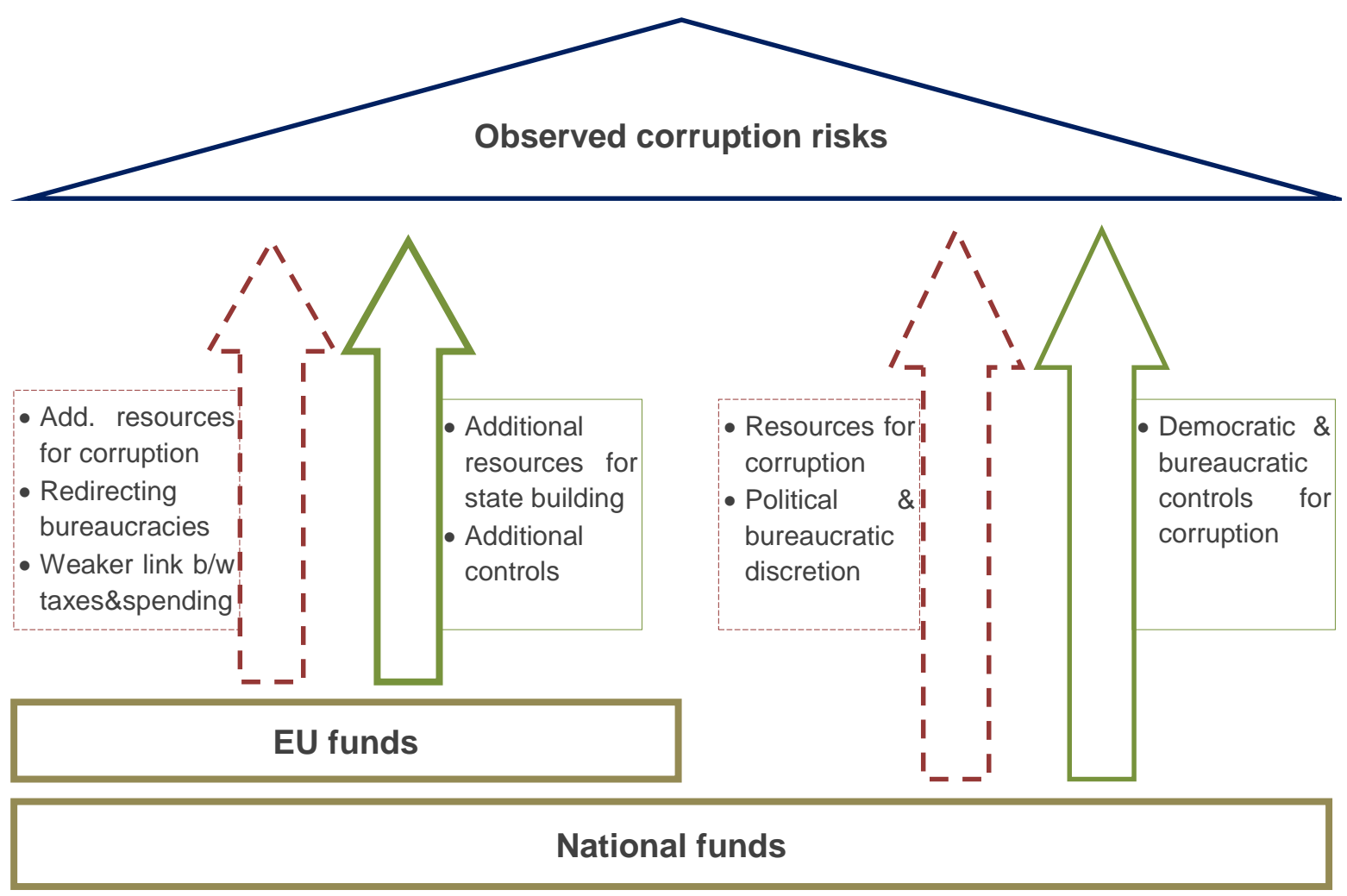




\section{Tables}

Table 1. Main statistics of the analysed data by country, total public procurement spending, 20092012

Czech Republic Hungary Total

\begin{tabular}{lccc} 
Total number of contracts awarded (with valid contract value) & 53,024 & 51,635 & 104,659 \\
\hline Total number of unique winners & 9,264 & 10,940 & 20,204 \\
\hline Total number of unique issuers & 4,432 & 5,295 & 9,727 \\
\hline Combined value of awarded contracts (million EUR) & 40,685 & 11,768 & 52,453 \\
\hline Combined value of awarded contracts (\% GDP)** & $6.8 \%$ & $3.1 \%$ & $5.3 \%$
\end{tabular}

Notes: * Exchanged into EUR using average monthly exchange rate of the contract award, not corrected for inflation; ${ }^{* *} G D P$ figures are from Eurostat (GDP at market prices). 
Table 2. Descriptive statistics of EU Funds spending by country, 2009-2012

\begin{tabular}{l|ccccc}
\multicolumn{2}{c}{ Ncontracts } & $\begin{array}{c}\text { TOTAL VALUE } \\
\text { (MILLION } \\
\text { EUR) }\end{array}$ & $\begin{array}{c}\text { \% OF } \\
\text { CONTRACTS } \\
\text { AWARDED }\end{array}$ & $\begin{array}{c}\text { \% OF TOTAL } \\
\text { PROCUREMENT } \\
\text { SPENDING }\end{array}$ & $\begin{array}{c}\text { \% OF GENERAL } \\
\text { GOVERNMENT } \\
\text { EXPENDITURE* }\end{array}$ \\
\hline $\begin{array}{l}\text { CZECH } \\
\text { REPUBLIC }\end{array}$ & 14,600 & 12,609 & $31.1 \%$ & $31.0 \%$ & $11.1 \%$ \\
HUNGARY & 14,110 & 5,663 & $34.4 \%$ & $48.1 \%$ & $12.7 \%$ \\
Note: * public procurement to general procurement expenditure ratio is obtained from (OECD, 2013).
\end{tabular}


Table 3. Summary of elementary corruption risk indicators

\begin{tabular}{|c|c|c|}
\hline PROC. PHASE & INDICATOR NAME & INDICATOR VALUES \\
\hline \multirow{5}{*}{ SUBMISSION } & Call for tenders publication & $\begin{array}{l}0=\text { call for tender published in official journal } \\
1=\text { NO call for tender published in official journal }\end{array}$ \\
\hline & Call for tender modification & $\begin{array}{l}0=\text { NOT modified call for tenders } \\
1=\text { modified call for tenders }\end{array}$ \\
\hline & Procedure type & $\begin{array}{l}0=\text { open procedure } \\
1=\text { non-open procedure (e.g. invitation tender) }\end{array}$ \\
\hline & Length of eligibility criteria & Number of characters relative to market average \\
\hline & $\begin{array}{l}\text { Length of advertisement } \\
\text { period }\end{array}$ & $\begin{array}{l}\text { Number of days between the publication of call for tenders and } \\
\text { the submission deadline (for short submission periods weekends } \\
\text { are deducted) }\end{array}$ \\
\hline \multirow{2}{*}{ ASSESSMENT } & $\begin{array}{l}\text { Weight of non-quantitative } \\
\text { evaluation criteria }\end{array}$ & $\begin{array}{l}\text { Sum of weights for evaluation criteria which are NOT related to } \\
\text { prices or quantities }\end{array}$ \\
\hline & Length of decision period & $\begin{array}{l}\text { number of days between submission deadline and announcing } \\
\text { contract award }\end{array}$ \\
\hline \multirow{2}{*}{ OUTCOME } & $\begin{array}{l}\text { Single bidder contract } \\
\text { (valid/received) }\end{array}$ & $\begin{array}{l}0=\text { more than } 1 \text { bid received } \\
1=1 \text { bid received }\end{array}$ \\
\hline & Winner contract share & $\begin{array}{l}\text { 12-month total contract value of winner / 12-month total awarded } \\
\text { contract value by issuer }\end{array}$ \\
\hline
\end{tabular}


Table 4. Summary statistics of corruption proxies used in the analysis

\begin{tabular}{lcc}
\hline corruption proxy & single bid & CRI \\
\hline mean & 0.319 & 0.301 \\
p25 & & 0.187 \\
p50 & & 0.268 \\
p75 & & 0.417 \\
standard deviation & 0.466 & 0.168 \\
$\mathrm{~N}$ & 84,682 & 82,438 \\
\hline \multicolumn{1}{c}{ mean by buyer size category (nr.of employees) } \\
\hline$<=10$ & 0.255 & 0.376 \\
$10<x<=25$ & 0.231 & 0.364 \\
$25<x<=50$ & 0.362 & 0.369 \\
$50<x<=100$ & 0.364 & 0.331 \\
$100<x<=500$ & 0.333 & 0.310 \\
$500<x$ & 0.291 & 0.279 \\
missing & 0.335 & 0.285 \\
\hline \multicolumn{3}{c}{ national } \\
regional/local & 0.398 & 0.305 \\
supported body & 0.327 & 0.300 \\
established by public law & 0.228 & 0.297 \\
other/private & 0.317 & 0.296 \\
missing & 0.349 & 0.330 \\
\hline
\end{tabular}


Table 5. Ordinary least-squares regressions of relative contract price, by country, 2009-2012

dependent variable

\section{country}

independent variables

single bid=1

sign.

CRI

sign.

each regression contains constant

control variables: type of issuer, number of employees, product market; year of contract award; log contract value

\begin{tabular}{c|cccc}
$N$ & 32,997 & 32,997 & 25,456 & 25,062 \\
$R^{2}$ & 0.13 & 0.10 & 0.05 & 0.05
\end{tabular}

Note: * $p<0.05$; ${ }^{* *} p<0.01$; ${ }^{* * *} p<0.001$; standard errors obtained using Monte Carlo random permutations (300 repetitions) in stata 12.0

relative contract price (contract price/estimated price)

\section{CZ}

$0.152^{* * *}$

0.000

$0.282^{\star * *}$

0.000
0.000 $0.221^{\text {***}}$
HU

$0.063^{* * *}$

0.000 
Table 6. Naïve and sophisticated comparisons of EU and non-EU funded tenders' single bid \% and CRI, 2009-2012, CZ-HU combined

Outcome variable

Single bid

CRI

Method

naive propensity naive

comparison score matching comparison

propensity

non-EU funded

0.281

0.304

0.290

score matching

EU funded

0.377

0.367

0.325

0.303

diff(EU funded - non-EU f.)

$0.096 * * *$

$0.063 * * *$

$0.035^{* * *}$

0.321

95\% conf.interval-lower bound

0.089

0.055

0.032

$0.018 * * *$

95\% conf.interval-upper bound

0.103

0.072

0.037

0.015

$\mathrm{N}$ non-EU funded

56,372

25,860

54,864

0.021

N EU-funded

27,917

25,860

27,365

25,533

Note: ${ }^{*} p<0.05 ;{ }^{* *} p<0.01 ;{ }^{* * *} p<0.001$; standard errors obtained using Monte Carlo random permutations (300 repetitions) in stata 12.0; propensity score matching using psmatch2, nearest neighbour, logit, no replacement, common 
Table 7. Summary of driving factors of CRI differences between EU and non-EU funded projects, 2009-2012, Number of Contracts $=85,777$

Corruption techniques diff. (EU funded - nonEU funded)

naive propensity

Procedure type comparison score matching

NO call for tenders published in o. journal $-0.060 * * *$ $-0.114 * * *$

Length of advertisement period

$0.015 * * *$

0.003

Length of eligibility criteria $-0.005 * * *$ 0.001

Weight of non-quantitative evaluation criteria

$0.074 * * *$

$0.086 * * *$

Length of decision period

$0.046^{* * *}$

$0.040 * * *$

Modification of call for tenders

$0.023 * * *$

$0.024 * * *$

Single bid

$0.034 * * *$

$0.036 * * *$

Winner contract share

$0.089 * * *$

$0.087^{* * *}$

Note: ${ }^{* * *} p<0.001,{ }^{* *} p<0.01,{ }^{*} p<0.05$ standard errors obtained using Monte Carlo random permutations (300 repetitions) in stata 12.0 
Table 8. Organisation-level linear and panel regressions of CRI on EU Funds spending share, organisations with at least 2 contracts per year for at least 2

\begin{tabular}{|c|c|c|c|c|c|c|}
\hline Model & $\begin{array}{l}\text { (1) } \\
\text { OLS }\end{array}$ & $\begin{array}{l}\text { (2) } \\
\mathrm{BE}\end{array}$ & $\begin{array}{l}\text { (3) } \\
R E\end{array}$ & $\begin{array}{l}\text { (4) } \\
\text { RE }\end{array}$ & $\begin{array}{l}\text { (5) } \\
\text { RE }\end{array}$ & $\begin{array}{l}\text { (6) } \\
\text { RE }\end{array}$ \\
\hline Dependent variable & \multicolumn{6}{|c|}{ Corruption Risk Index } \\
\hline EU Funds' share & $\begin{array}{c}0.0208^{\star * *} \\
(0.000)\end{array}$ & $\begin{array}{c}0.0364^{\star * *} \\
(0.000)\end{array}$ & $\begin{array}{c}0.0181^{* * *} \\
(0.000)\end{array}$ & & $\begin{array}{c}0.0117^{\star *} \\
(0.026)\end{array}$ & \\
\hline Lag EU Funds' share & & & & $\begin{array}{c}0.0214^{\star * *} \\
(0.000)\end{array}$ & $\begin{array}{c}0.0178^{\star * *} \\
(0.001)\end{array}$ & \\
\hline Ref. cat.: $0 \%$ EU Funds & & & & & & \\
\hline $0 \%<$ EU Funds' share $<36 \%$ & & & & & & $\begin{array}{l}0.0036 \\
(0.482)\end{array}$ \\
\hline $36 \%<$ EU Funds' share $<75 \%$ & & & & & & $\begin{array}{l}0.0041 \\
(0.433)\end{array}$ \\
\hline $75 \%<$ EU Funds' share $<100 \%$ & & & & & & $\begin{array}{l}0.0098^{*} \\
(0.077)\end{array}$ \\
\hline $100 \%$ EU Funds & & & & & & $\begin{array}{c}0.0240^{* \star \star} \\
(0.000)\end{array}$ \\
\hline Control variables & & & & & & \\
\hline Country & $\mathrm{x}$ & $x$ & $x$ & $x$ & $\mathrm{x}$ & $\mathrm{x}$ \\
\hline Organization type & $\mathrm{x}$ & $x$ & $x$ & $x$ & $\mathrm{x}$ & $\mathrm{x}$ \\
\hline Main sector & $\mathrm{x}$ & $\mathrm{x}$ & $\mathrm{x}$ & $\mathrm{x}$ & $\mathrm{x}$ & $\mathrm{x}$ \\
\hline Log spending value & $\mathrm{x}$ & $\mathrm{x}$ & $\mathrm{x}$ & $x$ & $\mathrm{x}$ & $\mathrm{x}$ \\
\hline Nr.of employees & $x$ & $x$ & $\mathrm{x}$ & $x$ & $\mathrm{x}$ & $\mathrm{x}$ \\
\hline Use of e-auctions & $\mathrm{x}$ & $\mathrm{x}$ & $x$ & $x$ & $\mathrm{x}$ & $\mathrm{x}$ \\
\hline Observations & 6495 & 6495 & 6495 & 4220 & 4220 & 6326 \\
\hline $\mathrm{N}$ (organisations) & & 2454 & 2454 & 2135 & 2135 & 2435 \\
\hline$R^{2}$ (overall) & 0.144 & 0.138 & 0.144 & 0.165 & 0.166 & 0.146 \\
\hline
\end{tabular}

Note: $p$-values in parentheses; $* * * p<0.01, * * p<0.05, * p<0.1$ 


\section{Appendices}

Appendix A - Public procurement data sources used

Table A1. Primary sources of public procurement data and minimum thresholds

\begin{tabular}{|l|ccc|}
\hline Country & $\begin{array}{c}\text { Institute holding and publishing } \\
\text { PPC data }\end{array}$ & $\begin{array}{c}\text { URL of national official } \\
\text { procurement journal }\end{array}$ & $\begin{array}{c}\text { Minimum reporting } \\
\text { thresholds (EUR) }\end{array}$ \\
\hline Czech Republic & Ministerstvo pro místní rozvoj ČR & $\frac{\text { https://www.vestnikverejnychzaka }}{\underline{\text { zek.cz/ }}}$ & 39,000 \\
Hungary & Közbeszerzési Hatóság & $\underline{\text { http://www.kozbeszerzes.hu/ }}$ & 27,300 \\
\hline
\end{tabular}

13 Thresholds refer to 2012, classical issuers, in services sector. National currencies are converted to EUR using official exchange rates of 5/2/2013 of the European Central Bank. 
Table B1 Binary logistic regression results on contract level, 2009-2012, by country, average marginal effects (nr. of winners $>=3$ and $\mathrm{nr}$. of contracts awarded in 12 months $>=3$ ) Dependent var: single bidder contract (1), multi-bidder contract (0) Czech Republic

Hungary

\begin{tabular}{|c|c|c|c|}
\hline \multicolumn{2}{|l|}{ Czech Republic } & \multicolumn{2}{|l|}{ Hungary } \\
\hline NO call for tenders in off.journal (open proc.) & $0.192 * * *$ & NO call for tenders in off.journal (open proc.) & $0.133^{* * *}$ \\
\hline sign. & 0.000 & sign. & 0.000 \\
\hline Procedure type & & Procedure type & \\
\hline ref. cat.=open procedure & & ref. cat.=open procedure & \\
\hline $1=$ invitation procedure & $-0.093 * * *$ & $1=$ invitation procedure & $0.06^{* * *}$ \\
\hline sign. & 0.000 & sign. & 0.000 \\
\hline $2=$ negotiation procedure & $0.09 * * *$ & $2=$ negotiation procedure & $0.065^{* * *}$ \\
\hline sign. & 0.000 & sign. & 0.000 \\
\hline 3=outside PP law & $-0.202 * * *$ & $3=0$ ther/framework procedure & $0.245^{* * *}$ \\
\hline sign. & 0.000 & sign. & 0.000 \\
\hline 4=other/missing/erroneous procedure type & 0.013 & 4=outside PP law & 0.003 \\
\hline sign. & 0.453 & sign. & 0.820 \\
\hline Length of eligibility criteria & & Length of eligibility criteria & \\
\hline ref.cat. $=$ criteria lenth $<-626.52$ & & ref.cat.= crit.length $<-2922.13$ & \\
\hline $2=-626.52<$ criteria length $<=864.32$ & $0.078 * * *$ & $2=-2922.13<$ crit.length $<=520.7$ & $0.037^{* * *}$ \\
\hline sign. & 0.000 & sign. & 0.000 \\
\hline $3=864.32<$ crit.length $<=3403.1$ & $0.056 * * *$ & $3=520.7<$ crit.length $<=2639.73$ & $0.081^{* * *}$ \\
\hline sign. & 0.000 & sign. & 0.000 \\
\hline $4=3403.1<$ crit.length & $0.111 * * *$ & $4=2639.73<$ crit.length & $0.085 * * *$ \\
\hline sign. & 0.000 & sign. & 0.000 \\
\hline $5=$ missing crit. length & 0.121 & $5=$ missing crit. length & $0.043^{* * *}$ \\
\hline sign. & 0.000 & sign. & 0.000 \\
\hline Modification of call for tenders & 0.012 & Modification of call for tenders & $-0.031 * *$ \\
\hline sign. & 0.103 & sign. & 0.007 \\
\hline Length of submission period & & Length of submission period & \\
\hline ref.cat. $=$ s.period $>60$ & & ref.cat. $=$ s. period $>20$ & \\
\hline $2=40<$ s. period $<=60$ & $0.063^{* * *}$ & $2=17<$ s. period $<=20$ & 0.001 \\
\hline sign. & 0.000 & sign. & 0.877 \\
\hline $3=37<$ s. period $<=40$ & $0.082^{* * *}$ & $3=5<$ s. period $<=14$ & $0.1 * * *$ \\
\hline sign. & 0.000 & sign. & 0.000 \\
\hline $4=19<$ s. period $<=37$ & $0.019 *$ & $4=0<$ s.period $<=5$ (incl.weekend) & $0.212 * * *$ \\
\hline sign. & 0.050 & sign. & 0.000 \\
\hline $5=0<=s$. period $<=19$ & $0.064 * * *$ & $5=$ missing & $0.089 * * *$ \\
\hline sign. & 0.000 & sign. & 0.000 \\
\hline $6=$ missing submission period & 0.043 & & \\
\hline sign. & 0.490 & & \\
\hline Weight of non-price evaluation criteria & & Weight of non-price evaluation criteria & \\
\hline ref.cat. $=0<$ non-price criteria $w .<=0.3$ & & ref.cat. $=0<$ non - price criteria $w .<=0.4$ & \\
\hline $1=$ non-price criteria $w .=0$ & $0.141^{* * *}$ & $1=$ non-price criteria $w .=0$ & $0.047^{* * *}$ \\
\hline sign. & 0.000 & sign. & 0.000 \\
\hline $3=0.3<$ non-price criteria $w .<=0.44$ & $0.038^{* * *}$ & $3=0.4<$ non-price criteria $w .<=0.556$ & $0.092 * * *$ \\
\hline sign. & 0.000 & sign. & 0.000 \\
\hline $4=0.44<$ non-price criteria $w .<=1$ & $0.078 * * *$ & $4=0.556<$ non-price criteria $w .<1$ & $0.118 * *$ \\
\hline sign. & 0.000 & sign. & 0.003 \\
\hline $5=$ missing criteria & $0.306 * * *$ & $5=0.9<=$ non-price criteria $w .<=1$ & $0.03^{* *}$ \\
\hline sign. & 0.000 & sign. & 0.003 \\
\hline Length of decision period & & Length of decision period & \\
\hline ref.cat. $=106<$ dec. period $<=170$ & & ref.cat. $=44<$ dec. period $<=182$ & \\
\hline $1=0<$ dec. period $<=54$ & $0.24^{* * *}$ & $1=0<$ dec. period $<=32$ & $0.14 * * *$ \\
\hline sign. & 0.000 & sign. & 0.000 \\
\hline $2=54<$ dec. period $<=78$ & $0.118^{* * *}$ & $2=32<$ dec period $<=44$ & $0.054 * * *$ \\
\hline sign. & 0.000 & sign. & 0.000 \\
\hline $3=78<$ dec period $<=106$ & $0.083 * * *$ & $4=182<$ dec. period & $0.162 * * *$ \\
\hline sign. & 0.000 & sign. & 0.000 \\
\hline $5=170<$ dec. period & $0.058^{* * *}$ & missing & $-0.041^{* *}$ \\
\hline sign. & 0.000 & sign. & 0.007 \\
\hline $6=$ missing decision period & $0.463 * * *$ & & \\
\hline sign. & 0.000 & & \\
\hline $\begin{array}{l}\text { constant included in each regression } \\
\text { control variables: type of issuer, number of }\end{array}$ & & & \\
\hline $\mathrm{N}$ & 44471 & & 32000 \\
\hline Pseudo-R2 & 0.256 & & 0.111 \\
\hline
\end{tabular}

Source: PPC; Note: * $p<0.05 ;{ }^{* *} p<0.01 ;{ }^{* *} p<0.001$; standard errors obtained using Monte Carlo random permutations (300 repetitions) in stata 12.0 
Appendix C - Goodness of propensity score matching

Figure C1. Common support in Czech Republic and Hungary, psgraph in psmatch2 package of stata 12.0

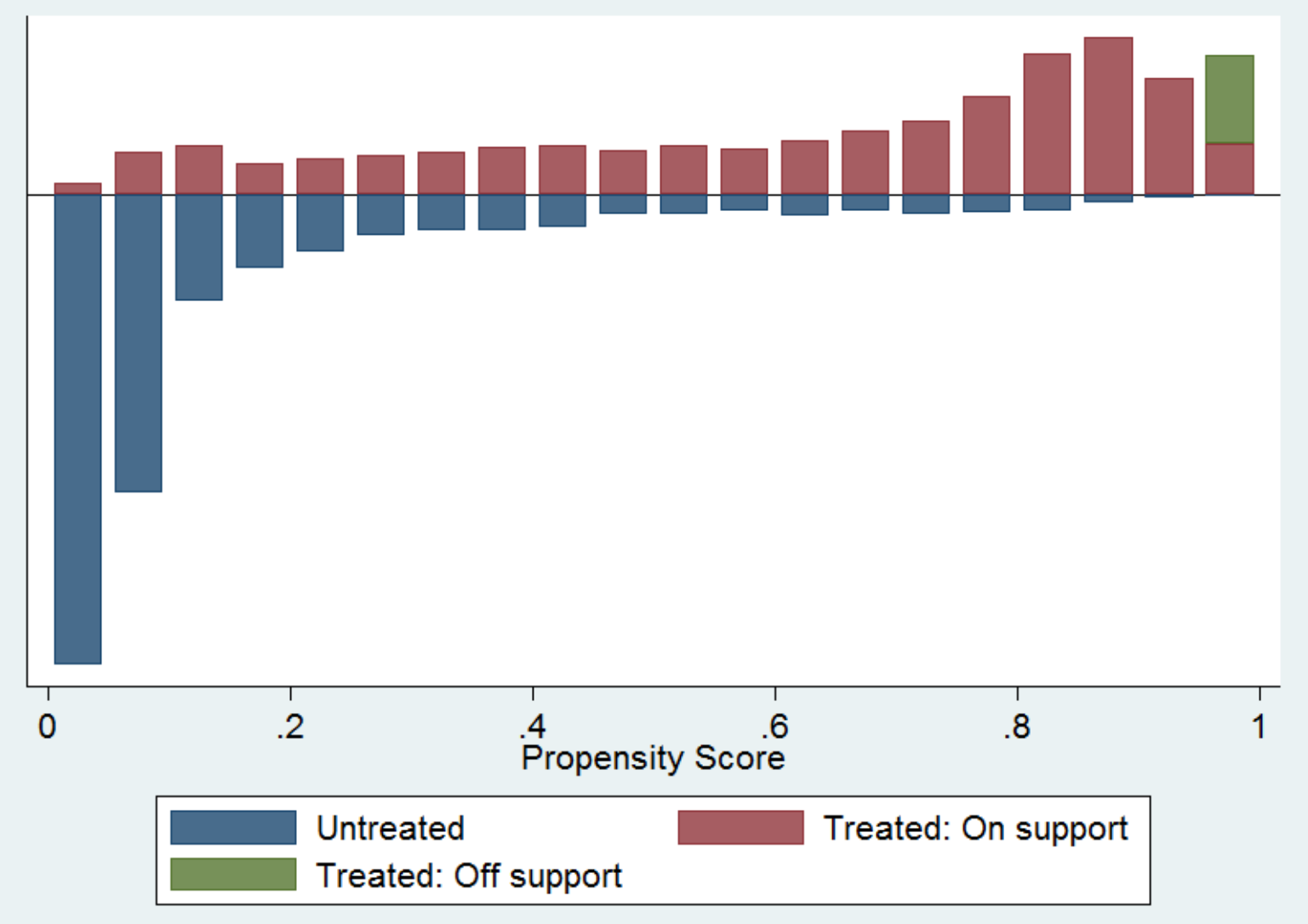


Figure C2. Balance of samples before and after matching on the variable level in Czech Republic and Hungary, psgtest in psmatch2 package of stata 12.0

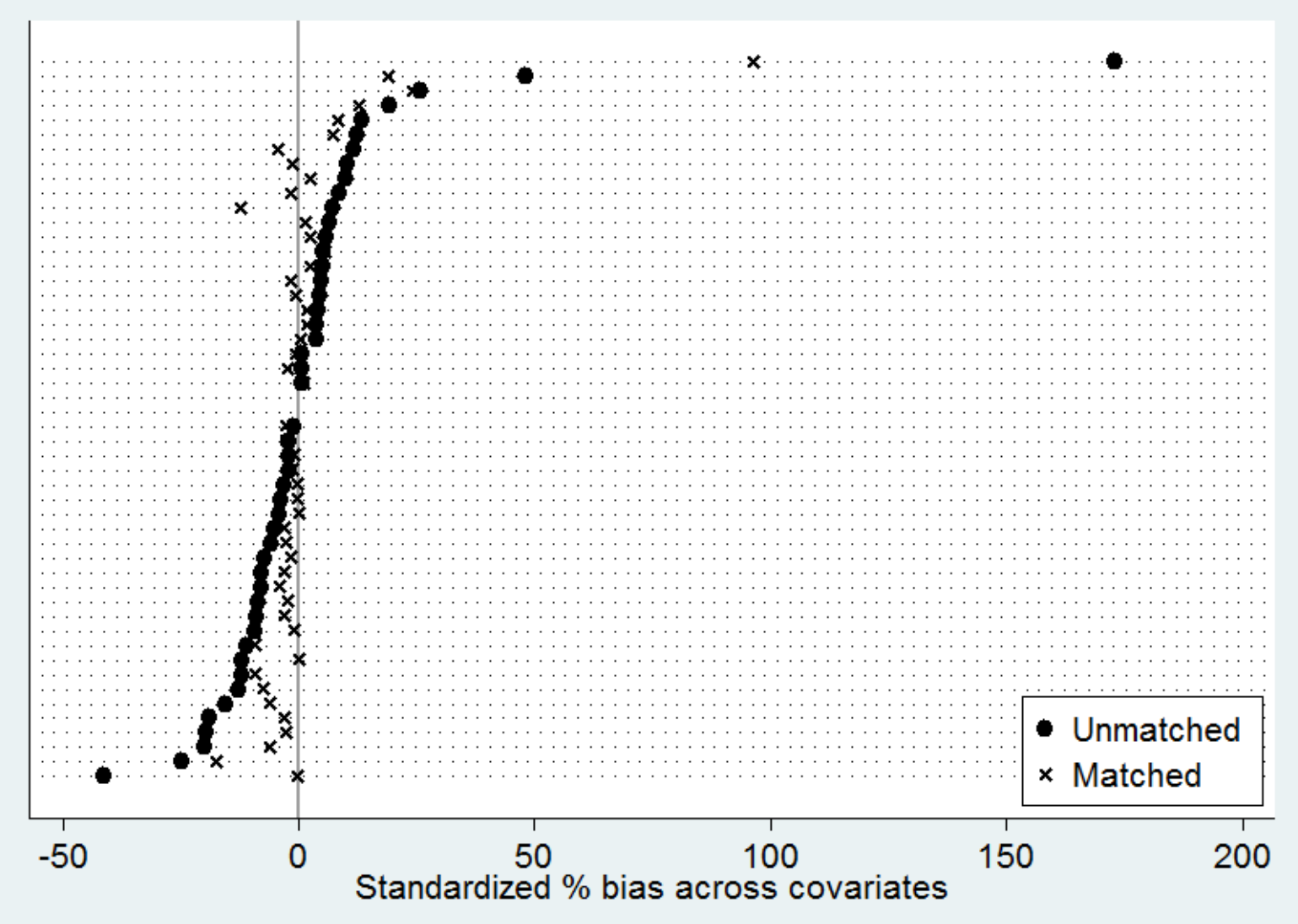


Table C1. Summary statistics of matching quality in Czech Republic and Hungary, pstest in psmatch2 package of stata 12.0

Sample

Unmatched

Matched
Ps R2

LR chi2

0.418

44119.9

0.223 p>chi2

0.000

0.000
MeanBias MedBias

13.6

6.9
7.9

2.4
R

1.10

1.75

\%Var 50

100 
Table D1. Matched comparisons of EU and non-EU funded tenders' single bid \% and CRI, 20092012, CZ-HU combined (contract value above 40,000 EUR)

Outcome variable

Method

non-EU funded

EU funded

diff(EU funded - non-EU f.)

95\% conf.interval-lower bound

$95 \%$ conf.interval-upper bound

$\mathrm{N}$ non-EU funded

N EU-funded

** $p<0.01 ; * * * 0<0.001 ;$

Single bid

naive

propensity comparison score matching comparison

$\begin{array}{cccc}0.284 & 0.273 & 0.315 & 0.312 \\ 0.338 & 0.337 & 0.331 & 0.330 \\ \mathbf{0 . 0 5 4 * * *} & \mathbf{0 . 0 6 3 ^ { * * * }} & \mathbf{0 . 0 1 6 * * *} & \mathbf{0 . 0 1 8 * * *} \\ 0.046 & 0.054 & 0.013 & 0.014 \\ 0.063 & 0.073 & 0.019 & 0.021 \\ 31,793 & 16,713 & 31,681 & 16,463 \\ 16,800 & 16,713 & 16,558 & 16,463\end{array}$

repetitions) in stata 12.0; propensity score matching using psmatch2, nearest neighbour, logit, no replacement, common

Table D2. Matched comparisons of EU and non-EU funded tenders' single bid \% and CRI, 20092012, CZ-HU combined (contract value above 140,000 EUR)

Outcome variable

Single bid

CRI

Method

non-EU funded

naive

propensity

naive

propensity comparison score matching comparison score matching

EU funded

0.262

0.240

0.330

0.321

0.290

0.289

0.337

0.336

diff(EU funded - non-EU f.)

$0.028 * * *$

$0.049 * * *$

$0.007^{* * *}$

$0.016^{* * *}$

95\% conf.interval-lower bound

0.017

0.037

0.003

0.011

95\% conf.interval-upper bound

0.040

0.062

0.011

0.021

$\mathrm{N}$ non-EU funded

31,793

16,713

31,681

16,463

16,800

16,713

16,558

16,463

Note: * $p<0.05$; ${ }^{* *} p<0.01 ;{ }^{* * *} p<0.001$; standard errors obtained using Monte Carlo random permutations (300 repetitions) in stata 12.0; propensity score matching using psmatch2, nearest neighbour, logit, no replacement, common 
Appendix E - Organisation-level regressions on single bidder ratio

Table E1. Organisation-level linear and panel regressions of single bidder ratio on EU Funds spending share, organisations with at least 2 contracts per year

\begin{tabular}{|c|c|c|c|c|c|c|}
\hline Model & $\begin{array}{l}1) \\
\text { OLS }\end{array}$ & $\begin{array}{l}\text { (2) } \\
\mathrm{BE}\end{array}$ & $\begin{array}{l}\text { (3) } \\
\mathrm{RE}\end{array}$ & $\begin{array}{l}\text { (4) } \\
\mathrm{RE}\end{array}$ & $\begin{array}{l}(5) \\
R E\end{array}$ & $\begin{array}{l}6) \\
R E\end{array}$ \\
\hline Dependent variable & \multicolumn{6}{|c|}{ single bidder ratio } \\
\hline EU Funds' share & $\begin{array}{c}0.0307^{* *} \\
(0.003)\end{array}$ & $\begin{array}{c}0.0675^{\star * *} \\
(0.000)\end{array}$ & $\begin{array}{c}0.0278^{\star *} \\
(0.003)\end{array}$ & & $\begin{array}{c}-0.0006 \\
(0.963)\end{array}$ & \\
\hline Lag EU Funds' share & & & & $\begin{array}{c}0.0550^{\star \star *} \\
(0.000)\end{array}$ & $\begin{array}{c}0.0552^{\star \star \star} \\
(0.000)\end{array}$ & \\
\hline Ref. cat.: $0 \%$ EU Funds & & & & & & \\
\hline $0 \%<$ EU Funds' share $<36 \%$ & & & & & & $\begin{array}{l}0.0258 \\
(0.051)\end{array}$ \\
\hline $36 \%<$ EU Funds' share $<75 \%$ & & & & & & $\begin{array}{l}0.0181 \\
(0.168)\end{array}$ \\
\hline 75\%<EU Funds' share $<100 \%$ & & & & & & $\begin{array}{c}0.0296^{* *} \\
(0.033)\end{array}$ \\
\hline $100 \%$ EU Funds & & & & & & $\begin{array}{c}0.0330^{* *} \\
(0.002)\end{array}$ \\
\hline Control variables & & & & & & \\
\hline Country & $X$ & $X$ & $X$ & $X$ & $X$ & $X$ \\
\hline Organization type & $X$ & $X$ & $\mathrm{x}$ & $X$ & $x$ & $x$ \\
\hline Main sector & $x$ & $x$ & $x$ & $x$ & $x$ & $x$ \\
\hline Log spending value & $x$ & $X$ & $x$ & $x$ & $\mathrm{X}$ & $x$ \\
\hline Nr.of employees & $x$ & $x$ & $x$ & $x$ & $x$ & $\mathrm{X}$ \\
\hline Use of e-auctions & $x$ & $x$ & $x$ & $x$ & $x$ & $x$ \\
\hline Observations & 7854 & 7854 & 7854 & 4925 & 4925 & 7599 \\
\hline $\mathrm{N}$ (organisations) & & 2572 & 2572 & 2355 & 2355 & 2559 \\
\hline$R^{2}$ (overall) & 0.044 & 0.039 & 0.044 & 0.032 & 0.032 & 0.042 \\
\hline
\end{tabular}

Note: $p$-values in parentheses; $* * * p<0.01, * * p<0.05, * p<0.1$ 
Appendix F - Municipal-level regressions on CRI

Table F1. Organisation-level linear and panel regressions of CRI on EU Funds spending share, municipalities with at least 2 contracts per year for at least 2

\begin{tabular}{|c|c|c|c|c|c|c|}
\hline Model & $\begin{array}{l}1) \\
\text { OLS }\end{array}$ & $\begin{array}{l}(2) \\
\mathrm{BE} \\
\end{array}$ & $\begin{array}{l}\text { (3) } \\
\mathrm{RE} \\
\end{array}$ & $\begin{array}{l}(4) \\
\mathrm{RE}\end{array}$ & $\begin{array}{l}(5) \\
\mathrm{RE}\end{array}$ & $\begin{array}{l}6) \\
\mathrm{RE} \\
\end{array}$ \\
\hline Dependent variable & \multicolumn{6}{|c|}{ Corruption Risk Index } \\
\hline EU Funds' share & $\begin{array}{c}0.0263^{* * *} \\
(0.000)\end{array}$ & $\begin{array}{c}0.0421^{* * *} \\
(0.000)\end{array}$ & $\begin{array}{c}0.0212^{* * *} \\
(0.000)\end{array}$ & & $\begin{array}{c}0.0214^{* * *} \\
(0.001)\end{array}$ & \\
\hline Lag EU Funds' share & & & & $\begin{array}{c}0.0245^{\star * *} \\
(0.000)\end{array}$ & $\begin{array}{c}0.0203^{* * *} \\
(0.002)\end{array}$ & \\
\hline \multicolumn{7}{|l|}{ Ref. cat.: 0\% EU Funds } \\
\hline $0 \%<$ EU Funds' share $<36 \%$ & & & & & & $\begin{array}{c}0.0181^{* *} \\
(0.013)\end{array}$ \\
\hline $36 \%<$ EU Funds' share $<75 \%$ & & & & & & $\begin{array}{c}0.0158^{* *} \\
(0.023)\end{array}$ \\
\hline $75 \%<$ EU Funds' share $<100 \%$ & & & & & & $\begin{array}{c}0.0225^{* * *} \\
(0.002)\end{array}$ \\
\hline $100 \%$ EU Funds & & & & & & $\begin{array}{c}0.0308^{* * *} \\
(0.000) \\
\end{array}$ \\
\hline \multicolumn{7}{|l|}{ Control variables } \\
\hline Country & $x$ & $x$ & $\mathrm{X}$ & $x$ & $x$ & $X$ \\
\hline Organization type & $x$ & $x$ & $x$ & $x$ & $x$ & $x$ \\
\hline Main sector & $x$ & $x$ & $x$ & $x$ & $x$ & $x$ \\
\hline Log spending value & $x$ & $x$ & $x$ & $x$ & $x$ & $x$ \\
\hline Nr.of employees & $x$ & $x$ & $x$ & $x$ & $x$ & $x$ \\
\hline Use of e-auctions & $x$ & $\mathrm{x}$ & $\mathrm{X}$ & $\mathrm{X}$ & $\mathrm{X}$ & $x$ \\
\hline Observations & 3711 & 3711 & 3711 & 2402 & 2402 & 3581 \\
\hline $\mathrm{N}$ (organisations) & & 1473 & 1473 & 1243 & 1243 & 1456 \\
\hline$R^{2}$ (overall) & 0.12 & 0.114 & 0.119 & 0.13 & 0.134 & 0.123 \\
\hline
\end{tabular}

Note: $p$-values in parentheses; $* * * p<0.01, * * p<0.05, * p<0.1$ 
Appendix G - Additional descriptive statistics of the main variables used in the analysis

Figure G1. Yearly histograms of log contract values, Czech Republic

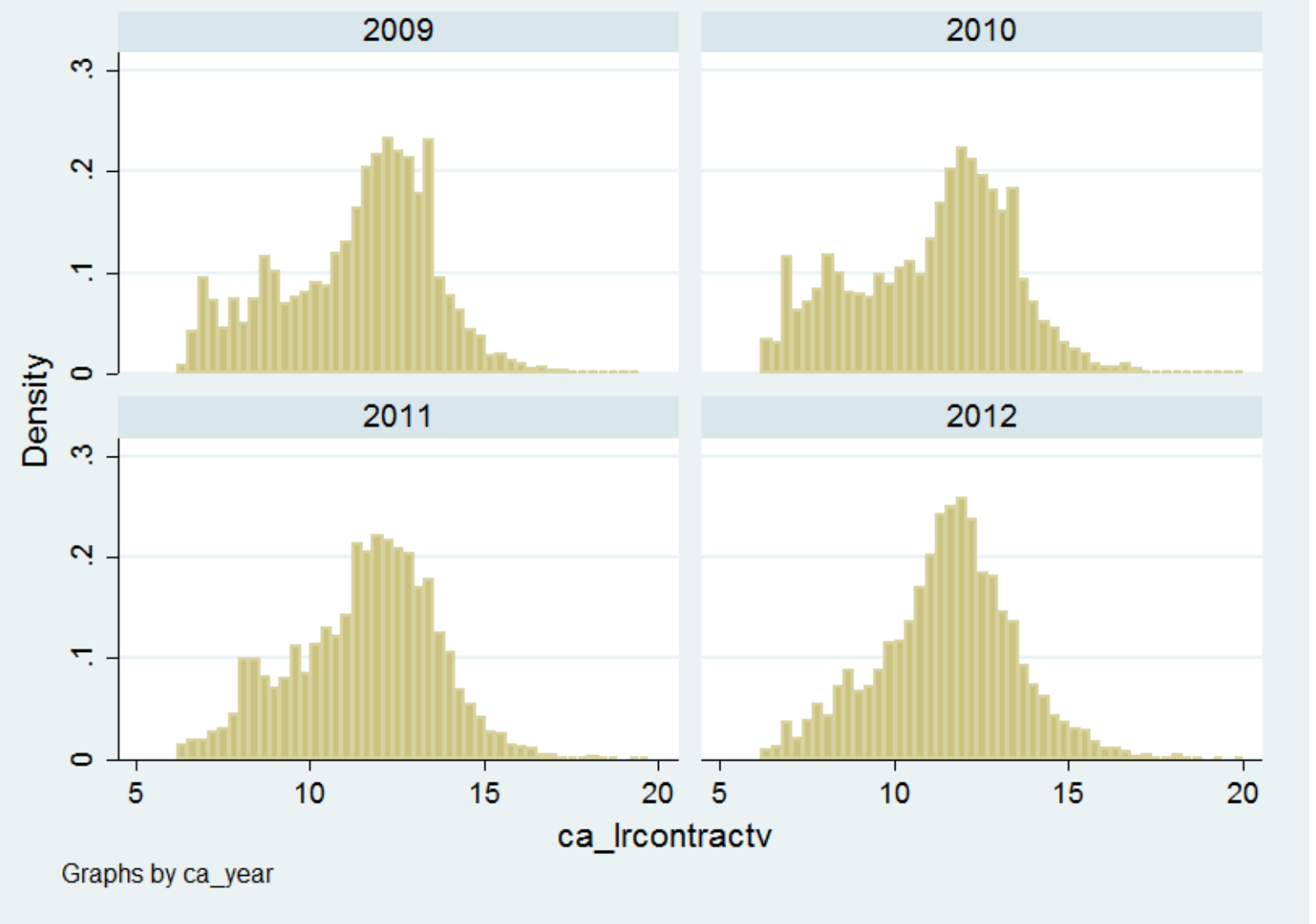


Figure G2. Yearly histograms of log contract values, Hungary

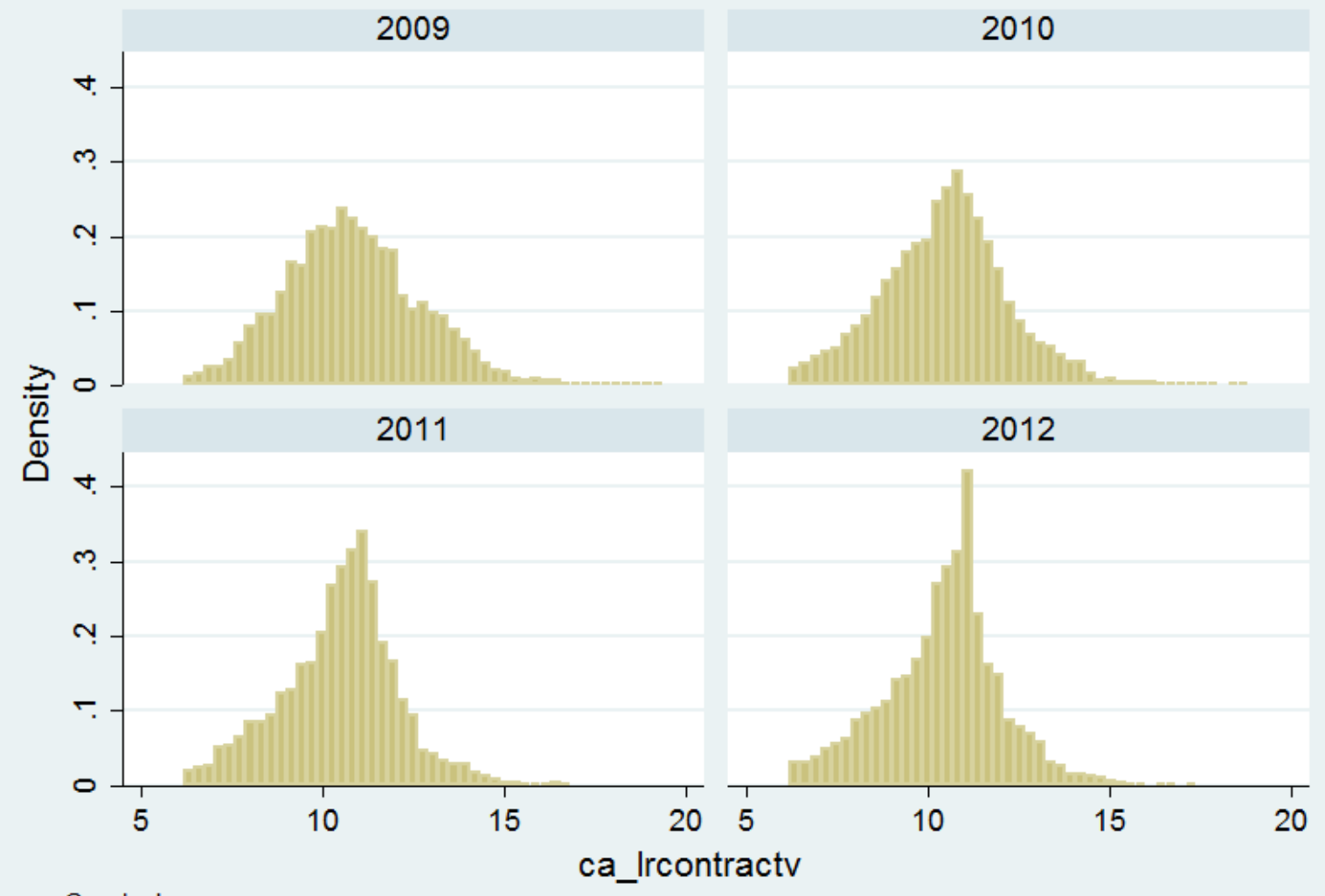

Graphs by ca_year

Table G1. Number of contracts awarded by country, year and funding source

$\begin{array}{llccccc} & & \mathbf{2 0 0 9} & \mathbf{2 0 1 0} & \mathbf{2 0 1 1} & \mathbf{2 0 1 2} & \text { Total } \\ \text { Czech } & \text { national funds } & \mathbf{1 0 , 5 7 2} & 8,841 & \mathbf{7 , 1 2 0} & 8,780 & 35,313 \\ \text { Republic } & \text { EU Funds } & 3,458 & 4,904 & 4,176 & 5,173 & 17,711 \\ & \text { national funds } & 7,641 & 10,814 & 7,718 & 5,458 & 31,631 \\ \text { Hungary } & \text { EU Funds } & 3,093 & 6,356 & 5,796 & 4,475 & 19,720\end{array}$


Figure G3. Quarterly average single bidder ratio by funding source(unmatched samples), Czech Republic

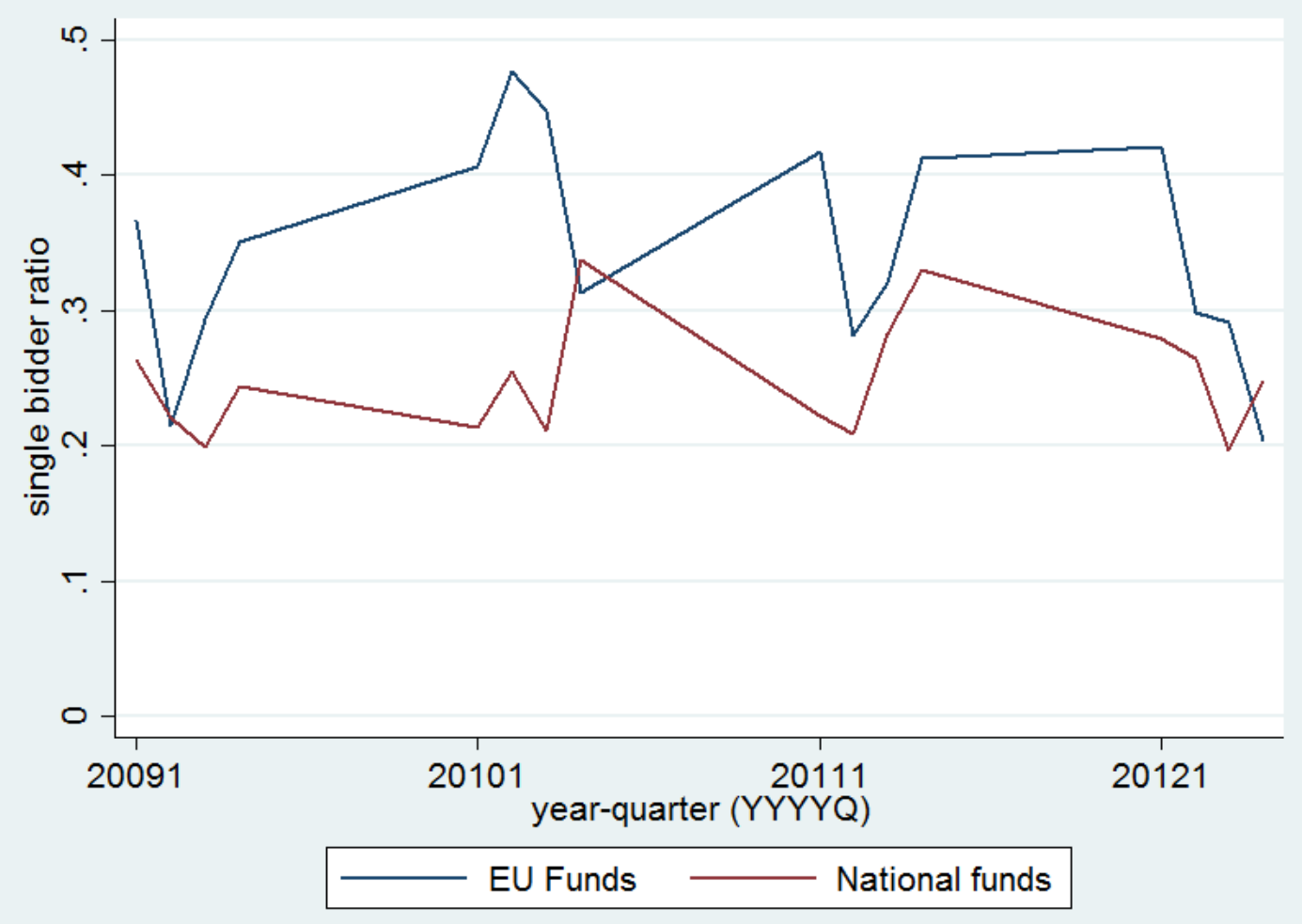

Figure G4. Quarterly average single bidder ratio by funding source(unmatched samples), Hungary

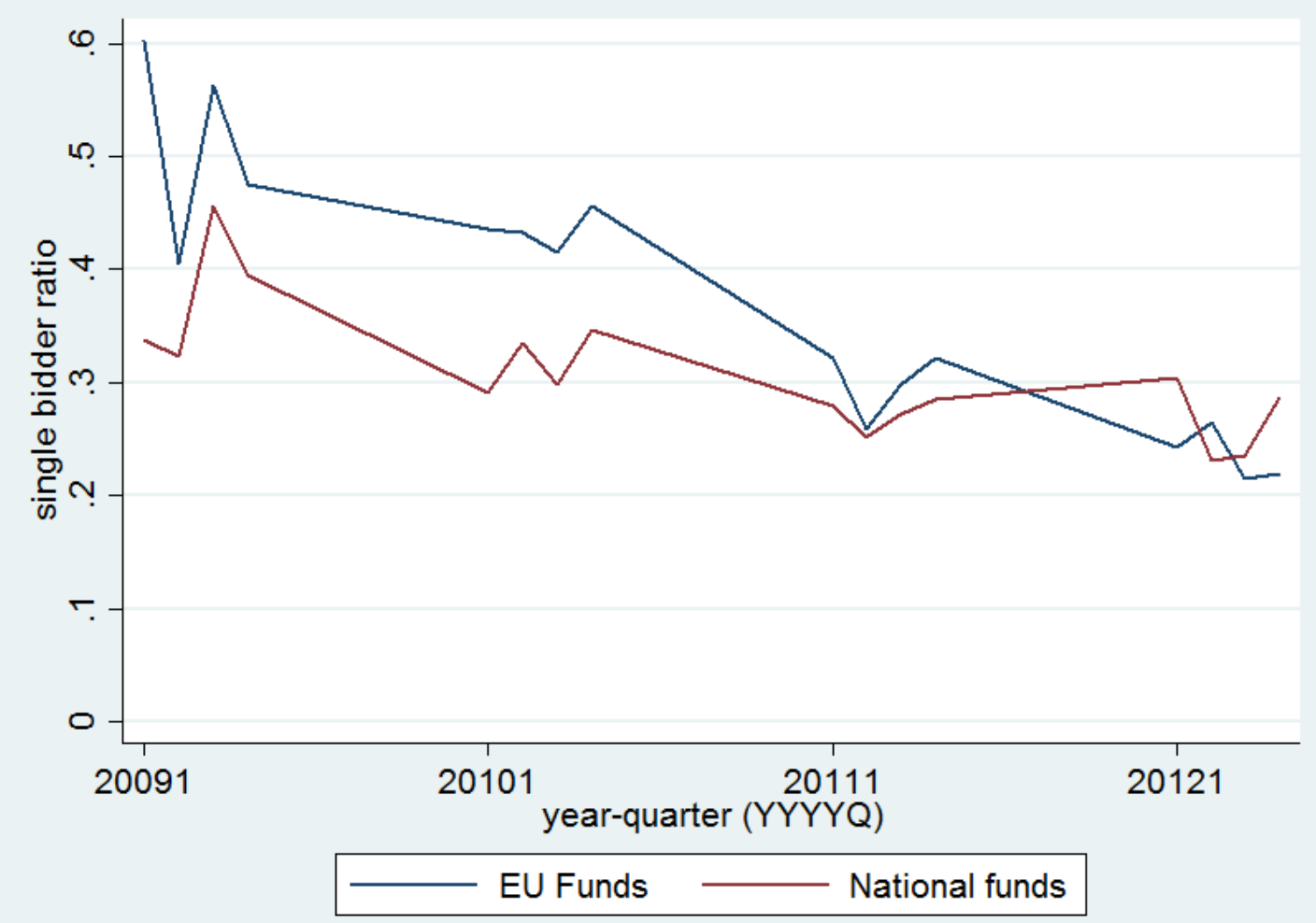


Figure G5. Quarterly average CRI by funding source (unmatched samples), Czech Republic

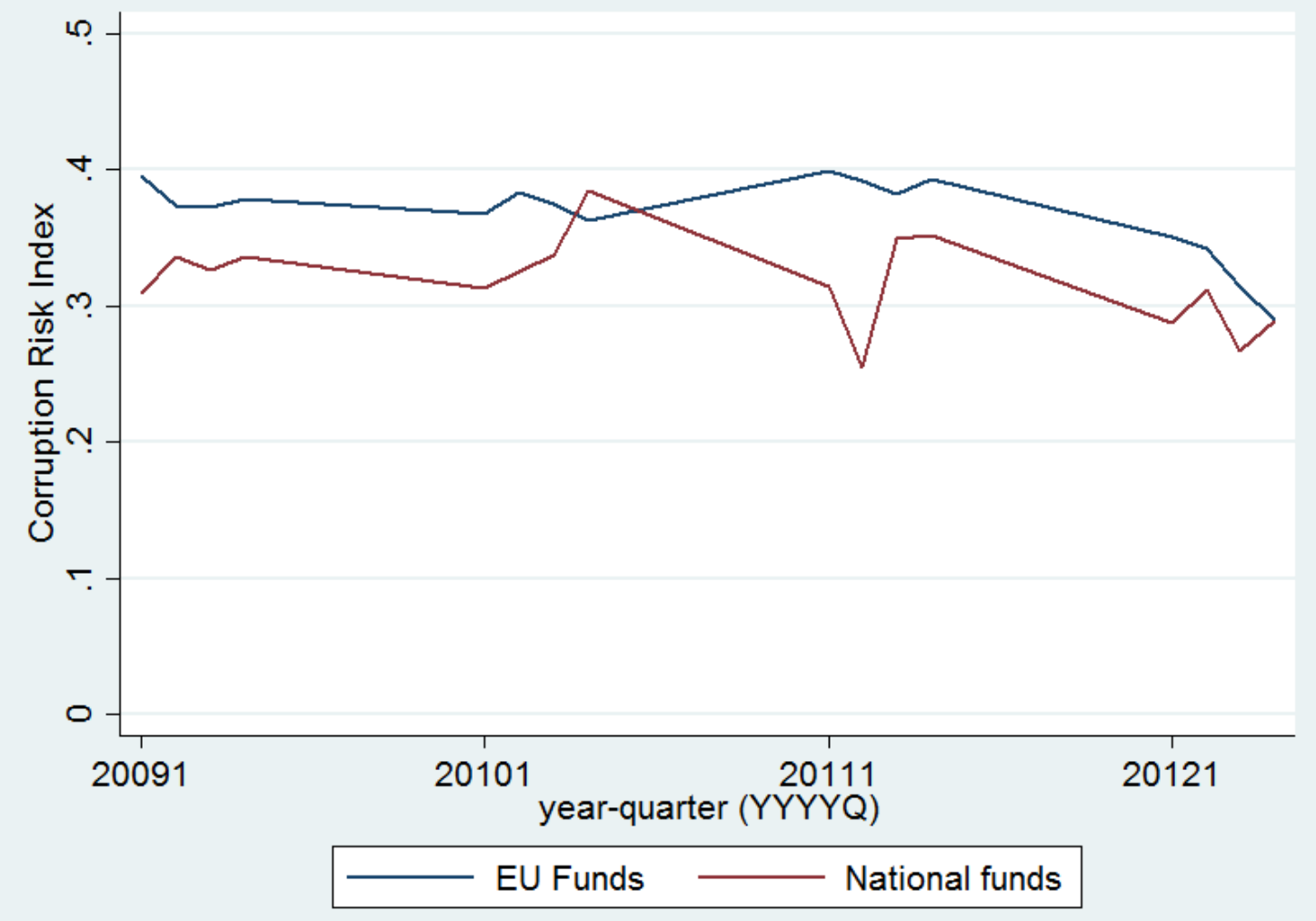

Figure G6. Quarterly average CRI by funding source (unmatched samples), Hungary

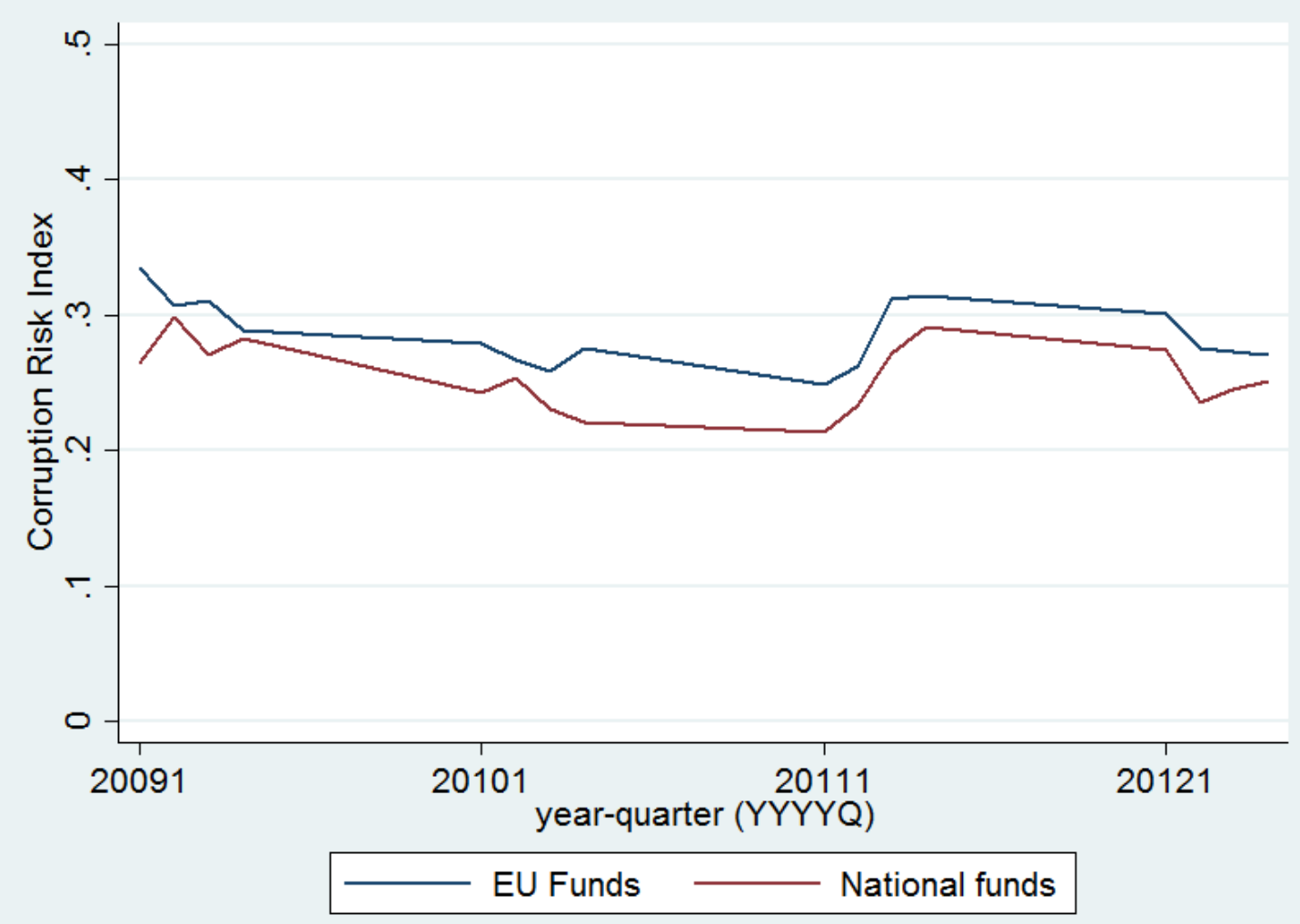


51 